\title{
Early changes in the urine proteome in a rat liver tumor model
}

\author{
Yameng Zhang ${ }^{1}$, Yufei Gao ${ }^{2}$, Youhe Gao ${ }^{1^{*}}$ \\ ${ }^{I}$ Department of Biochemistry and Molecular Biology, College of Life Sciences, Beijing Normal \\ University, Gene Engineering Drug and Biotechnology Beijing Key Laboratory, \\ Beijing 100875, China \\ ${ }^{2}$ College of Information Science and Technology, Beijing Normal University, Beijing 100875, China \\ *Corresponding author: Youhe Gao \\ Email: gaoyouhe@bnu.edu.cn
}

Phone: 86-10-5880-4382; Fax: 86-10-6521-2284

\begin{abstract}
Urine, as a potential biomarker source among the body fluids, can accumulate many changes in the body due to the lack of a mechanism to maintain a homeostatic state. Previous studies have demonstrated that proteomic technology can find many potential biomarkers to reflect different diseases in the urine. This study aims to detect early changes in the urinary proteome in a rat liver tumor model. The tumor model was established with the Walker-256 carcinosarcoma cell line (W256). Compared to before the injection, ninety-five differential proteins were significantly changed in the experimental rats. At day 3 , twelve proteins were identified in the absence of pathological changes, and four of them were altered at all four time-points (B2MG, VCAM1, HA11, and LG3BP). Seven had previously been associated with liver cancer. At day 5, fifty-two differential proteins were identified. At day 7 and day 11, there was a significant decrease in the body weight of the rats, and tumor tissue was observed in the liver. Fifty-two and forty differential proteins were changed significantly at day 7 and day 11, respectively. Of the proteins that were identified at these three time-points, and twenty-four were reported to be associated with liver cancer. Comparing the differential urinary proteins and biological processes of liver tumor model with those in different models of W256 grown in other organs, specific differential protein patterns were found among the four models, which indicates that the differential urinary proteins can reflect the differences when the same tumor cell grown in different organs.

Significance: This study demonstrated that (1) the rat liver tumor model caused early changes in urinary proteins may give new insight into the early diagnosis of liver cancer; (2) the same tumor cell grown in different organs can be reflected in differential urinary proteins.
\end{abstract}

Keywords: Urine; Proteomics; Liver tumor; Biomarkers

\section{Introduction}

Liver cancer is the third leading cause of cancer mortality in the world, and the latest dataset on urban cancer in China also noted that liver cancer has one of the top three highest cancer mortalities ${ }^{[1]}$. It has the characteristics of substantial morbidity and mortality. The early detection of in situ or invasive carcinoma may prevent cancerous metastatic processes; therefore, it can significantly improve survival rates for cancer patients. Despite the technology of diagnosis to detect the cancer having advanced so quickly in the last decade, there are still many patients who cannot be diagnosed at early disease stages. To reduce mortality from cancer, novel approaches must be considered for early detection. One effective 
strategy to improve the prognosis of liver cancer is to find the tumor in the early stage, when the patients have no obvious symptoms so that liver function can be preserved as much as possible and more effective treatments can be applied. Early diagnosis and treatment are the most effective ways to prevent and treat cancer and reduce mortality ${ }^{[2]}$.

Currently, liver cancer diagnosis mainly relies on detection with imaging equipment (such as ultrasound, CT and MRI) and biomarkers; however, images are susceptible to operator experience, and it is difficult to distinguish between liver cancer and nonmalignant hyperplasia. It can also be hard to detect many small nodules in the early stage. Approximately $22 \%$ of early liver cancer imaging is not typical ${ }^{[3]}$. On the other hand, tumor biomarkers are used simpler to employ, but there are many challenges. For instance, alpha-fetoprotein (AFP), which rapidly decreases in serum after birth and is maintained at a low level throughout adulthood, is the most widely used biomarker for liver cancer ${ }^{[4]}$; however, serum AFP is not sufficient for diagnosis due to its poor sensitivity and specificity. Previous research suggests that no single serum biomarker can predict liver cancer with optimal sensitivity and specificity, particularly in the early stage ${ }^{[5]}$.

Urine is known to play an important role in body fluids and can reflect many changes in the body due to the lack of a mechanism to maintain a homeostatic state ${ }^{[6]}$. This is the main distinction between blood and urine. Many studies have demonstrated that proteomic technology can be used to find many potential biomarkers to reflect different diseases in the urine, such as glomerular diseases ${ }^{[7]}$, obstructive nephropathy ${ }^{[8]}$, hepatic fibrosis ${ }^{[9]}$, autoimmune myocarditis ${ }^{[10]}$, subcutaneous tumors ${ }^{[11]}$ and glioma ${ }^{[12]}$.

Animal models can help to us to better understand liver cancer and also have less complicated genetics, living and other conditions to monitor the development of the disease. In clinical studies, it is difficult to collect samples from a large number of liver cancer patients in the early stage. Before the onset of obvious symptoms, animal models can employ conditional control of the disease development process and provide more clues to find early biomarkers. This study used liquid chromatography coupled with tandem mass spectrometry (LC-MS/MS) to detect the urinary proteome in a rat liver tumor model. Several differential proteins associated with liver cancer were observed, and new evidence for biomarkers in the early stage was obtained.

\section{Materials and methods}

\subsection{Animals}

Male Wistar rats $(130 \pm 20 \mathrm{~g})$ were purchased from Beijing Vital River Laboratory Animal Technology Co., Ltd. The animal license was SCXK (Beijing) 2016-0006. All experiments were approved by Institutional Animal Care Use \& Welfare Committee of the Institute of Basic Medical Sciences, Peking Union Medical College (Animal Welfare Assurance Number: ACUC-A02-2014-007). All rats were housed under a standard 12-h light/12-h dark cycle, and the room temperature and humidity were maintained at a standard level $\left(22 \pm 1^{\circ} \mathrm{C}, 65-70 \%\right)$.

\subsection{Tumor cell line and Culture}

Walker 256 tumor cells were cultured in the ascitic fluid of Wistar rats. All cells were harvested from the rats who were given an intraperitoneal injection of 107 Walker 256 carcinoma cells after two cycles of $7 \mathrm{~d}$ cell passage. Then, W256 cells were resuspended in phosphate-buffered saline (PBS) before injection. The viability of the cells was detected by the Trypan blue exclusion test using a Neubauer chamber.

\subsection{Rat models of liver cancer}

A tumor-bearing animal model was established in this study. All Wistar rats were randomly divided 
into different groups: the control group $(\mathrm{n}=5)$, and the Walker-256 (W256) tumor-bearing group $(\mathrm{n}=12)$. After anesthesia, the left medial lobe of the liver was exposed. W256 cells $\left(2.5 \times 10^{5}\right)$ were visually injected under the hepatic capsule into this lobe. The injection volume is $0.1 \mathrm{ml}$. An equal volume of PBS was also injected into the same location of the control rats.

\subsection{Histological analysis}

In the W256 model, the livers of the experimental and control rats were harvested $0,3,5,7,11$ and $18 \mathrm{~d}$ after injection. For histopathology, the liver was fixed in formalin (4\%) and embedded in paraffin. Then, all samples were sectioned and evaluated with hematoxylin and eosin (H\&E) staining.

\subsection{Urine collection and sample preparation}

Urine samples of the W256 model were collected at four time-points, day 3, day 5, day 7 and day 11. Without any treatment, urine was collected from each rat by metabolic cage alone overnight. All rats were fasted and banned while collecting the urine sample. The urine samples were stored at $-80^{\circ} \mathrm{C}$ for later use. Before LC-MS/MS analysis, the urine samples were thawed and transferred to centrifuge tubes for centrifugation at $12,000 \times \mathrm{g}$ for $30 \mathrm{~min}$ at $4{ }^{\circ} \mathrm{C}$ to remove impurities. The samples were mixed with three volumes of prechilled ethanol, and the supernatants were precipitated at $-20{ }^{\circ} \mathrm{C}$ for $2 \mathrm{~h}$. The mixtures were centrifuged for $30 \mathrm{~min}$ at $4{ }^{\circ} \mathrm{C}$, the supernatant was removed, and the precipitate was dissolved in a configured lysis buffer ( $8 \mathrm{~mol} / \mathrm{L}$ urea, $2 \mathrm{~mol} / \mathrm{L}$ thiourea, $50 \mathrm{mmol} / \mathrm{L}$ Tris, and $25 \mathrm{mmol} / \mathrm{L}$ DTT). After the dissolution was completed, the centrifugation was continued at $12,000 \times \mathrm{g}$ for $30 \mathrm{~min}$ at $4{ }^{\circ} \mathrm{C}$, then the supernatant was preserved. The protein concentration was determined by the Bradford assay. The urinary proteins at different time-points were digested using the FASP method ${ }^{[13]}$. One hundred micrograms of protein were added to the $10 \mathrm{kDa}$ filter device (Pall, Port Washington, NY, USA) for each sample, and the protein was washed several times in sequence with the prepared UA $(8 \mathrm{~mol} / \mathrm{L}$ urea, $0.1 \mathrm{~mol} / \mathrm{L}$ Tris$\mathrm{HCl}, \mathrm{pH} 8.5$ ) and $25 \mathrm{mmol} / \mathrm{L} \mathrm{NH}_{4} \mathrm{HCO}_{3}$ solutions. The protein samples were reduced with $20 \mathrm{mmol} / \mathrm{L}$ dithiothreitol (DTT, Sigma) at $37{ }^{\circ} \mathrm{C}$ for $1 \mathrm{~h}$ and then added to $50 \mathrm{mmol} / \mathrm{L}$ iodoacetamide (IAA, Sigma) for $30 \mathrm{~min}$ in the dark. The sample was centrifuged at $14,000 \times \mathrm{g}$ for $30 \mathrm{~min}$ at $18{ }^{\circ} \mathrm{C}$, then washed by UA and $\mathrm{NH}_{4} \mathrm{HCO}_{3}$, and trypsin (enzyme-to-protein ratio of 1:50) was added for overnight digestion at $37{ }^{\circ} \mathrm{C}$. Oasis HLB cartridges (Waters, Milford, MA) were used to desalt the peptide mixtures and dried by vacuum evaporation, then labeled for storage at $-80{ }^{\circ} \mathrm{C}$.

\subsection{LC-MS/MS analysis}

An EASY-nLC 1200 HPLC system (Thermo Fisher Scientific, USA) was used to separate the peptides. First, the peptides were acidified with $0.1 \%$ formic acid, their concentrations were determined by the BCA assay and then, they were diluted to $0.5 \mu \mathrm{g} / \mu \mathrm{L}$ with UA. Then, $1 \mu \mathrm{g}$ of each peptides sample was loaded on the rap column (Acclaim PepMap ${ }^{\circledR} 100,75 \mu \mathrm{m} \times 100 \mathrm{~mm}, 2 \mu \mathrm{m}$, nanoViper C18) at 0.3 $\mu \mathrm{L} / \mathrm{min}$ (column flow rate) for $1 \mathrm{~h}$ (elution time). The elution gradient of mobile phase $\mathrm{B}$ was $5 \%$ to $40 \%$ (mobile phase A: $0.1 \%$ formic acid; mobile phase B: $89.9 \%$ acetonitrile). A Thermo Orbitrap Fusion Lumos Tribrid mass spectrometer (Thermo Fisher Scientific, USA) was used for analysis ${ }^{[14]}$. Survey MS scans were acquired by the Orbitrap in a 350-1550 m/z range with the resolution set to 120,000 . For the MS/MS scan, the resolution was set at 30,000, and the HCD collision energy was chosen to be 30 . Dynamic exclusion was employed with a 30 -s window. Fifteen urine samples from three randomly selected experimental rats and three control rats at four time-points (days 3, 5, 7, and 11) were chosen for MS analysis. For each sample, two technical replicate analyses were performed.

\subsection{Data analysis}

All MS data were searched using Mascot Daemon software (version 2.5.1, Matrix Science, UK) with the SwissProt_2017_02 database (taxonomy: Rattus; containing 7992 sequences). The conditions 
included the following: trypsin digestion was selected, 2 sites of leaky cutting were allowed, cysteine was fixedly modified, methionine oxidation and protein $\mathrm{N}$-terminal acetylation were mutagenic, peptide mass tolerance was set to $10 \mathrm{ppm}$ and fragment mass tolerance was set to $0.05 \mathrm{Da}$. For statistical analyses that compared between the four-time points, one-way ANOVAs were performed. The differential proteins were screened with the following criteria: proteins with at least two unique peptides were allowed; fold change in increased group $\geq 1.5$ and fold change in decreased group $\leq 0.67$; and $\mathrm{P}<0.05$ by independent sample t-test. Group differences resulting in $\mathrm{P}<0.05$ were identified as statistically significant. All results are expressed as the mean \pm standard deviation.

\subsection{Functional annotation of the differential proteins}

All differential proteins identified at the different time-points were analyzed by DAVID 6.8 (https://david.ncifcrf.gov/) and Ingenuity Pathway Analysis (IPA) to determine the functional annotation. The proteins were described in detail according to three aspects including biological process, cellular component and molecular function. 


\section{Results and Discussion}

\subsection{Body weight and histopathological characterization over time}

There was a significant difference in body weight in the Walker 256 tumor-bearing rats over the seven days (Fig. 1). After W256 cell implantation, the average body weight of the tumor-bearing rats was lower than the controls, and reduced food and water intake was observed in the tumor-bearing rats. On day 16, a tumor-bearing rat died. All rats were sacrificed on day 18.

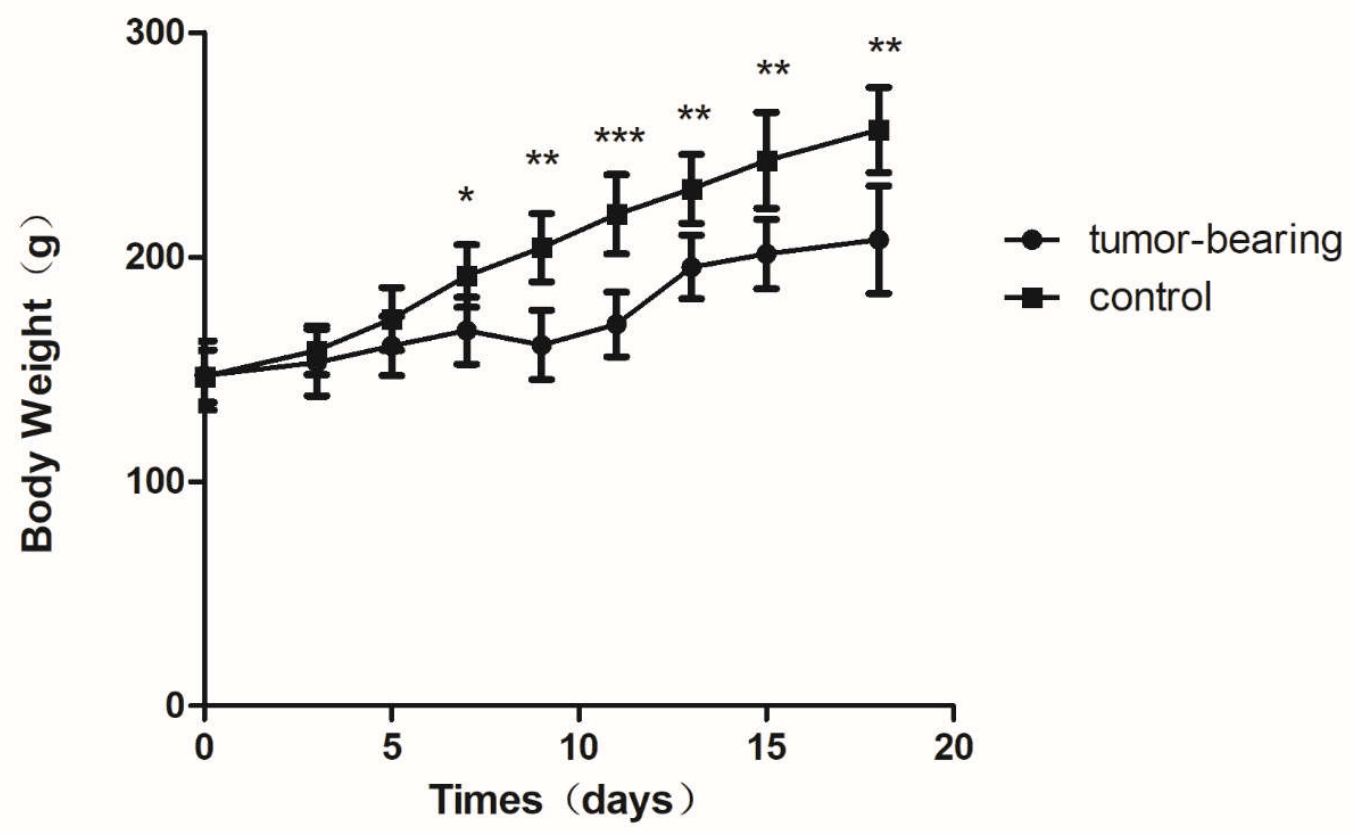

Fig. 1. Body weights of Walker 256 tumor-bearing rats. The average body weight of the tumor group was significantly lower than that of the control group ( $\mathrm{n}=6$ rats in the tumor group and $\mathrm{n}=5$ rats in the control group; * indicates $\mathrm{p}<0.05 ; * *$ indicates $\mathrm{p}<0.01 ; * * *$ indicates $\mathrm{p}<0.001)$.

H\&E staining of HCC in the W256 rats showed that as the disease progressed to different stages, pathological changes increased. At day 3, the H\&E staining showed that there were no obvious pathological changes. At day 7 and day 11, H\&E staining observed carcinosarcoma cells under the microscope and the liver tissues revealed heterogeneously necrotizing tumors and liver tissue during tumor progression. At day 18, all the experimental rats exhibited fibrosis and the huge tumor that was viable while adjacent liver tissue was necrotizing (Fig. 2). 
Day 0

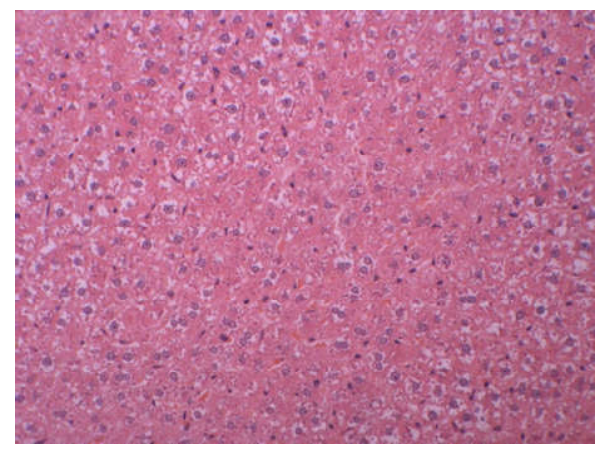

Day 5

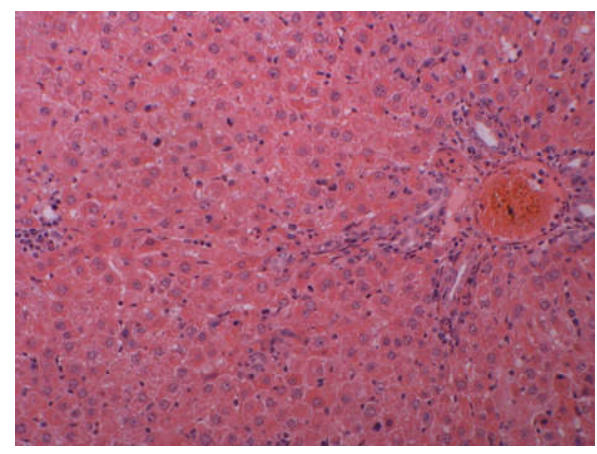

Day 11

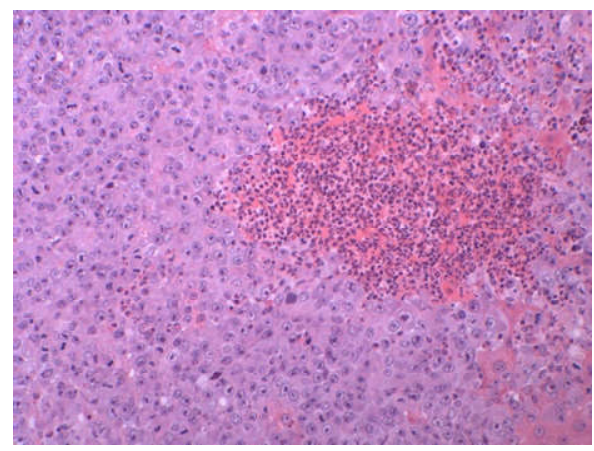

Day3

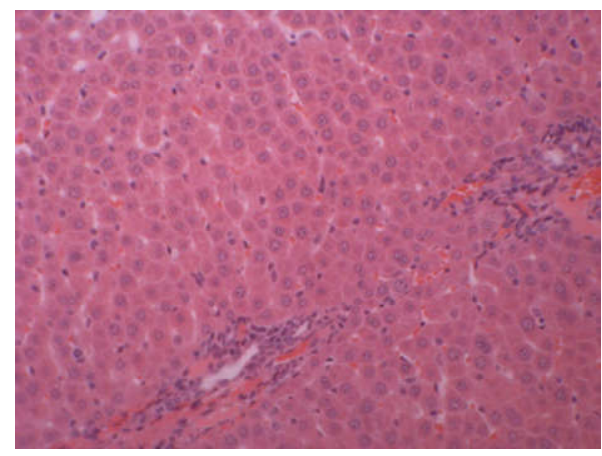

Day7

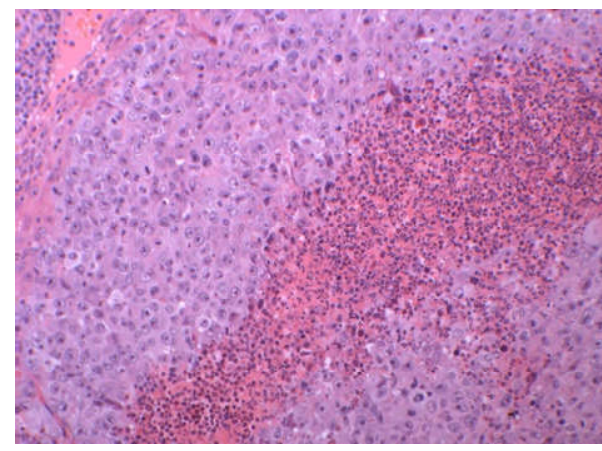

\section{Day18}

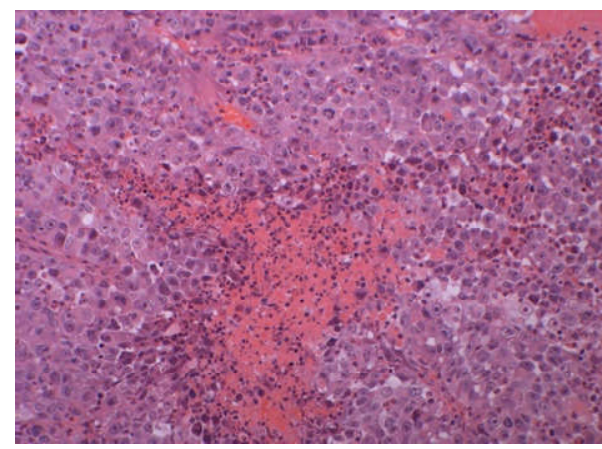

Fig. 2. Histopathological characterization after implantation(200X).

\subsection{Urine proteome changes in W256 model}

To investigate how the urine proteome changes with tumor progression, urine samples from the four time-points (days 3, 5, 7, and 11) in three experimental rats and three control rats were chosen for MS analysis. In total, 663 urinary proteins were identified, and all proteins are listed in Table S1. Among these, there are 108 differential proteins and only 95 differential proteins that had human orthologs were identified that significantly changed in all rats (fold change $\geq 1.5$ or $\leq 0.67, \mathrm{P}<0.05$; Table 1 ).

At day 3, twelve differential proteins, nine of which that increased and three of which that decreased, were identified. At day 5, fifty-two differential proteins, twenty of which that increased and thirty-two of which that decreased, were identified. At day 7, fifty-two differential proteins, twenty-two of which that increased and thirty of which that decreased, were identified. At day 11, forty differential proteins, 
bioRxiv preprint doi: https://doi.org/10 1101/568246; this version posted March 5, 2019. The copyright holder for this preprint (which was not certified by peer review) is the author/funder. All rights reserved. No reuse allowed without permission.

thirteen of which that increased and twenty-seven of which that decreased, were identified. The details of the differential proteins are shown in Table S2. Four proteins (B2MG, VCAM1, HA11, LG3BP) were altered at all four time-points, and the trend was consistent at each time-point (Fig. 3B).

A
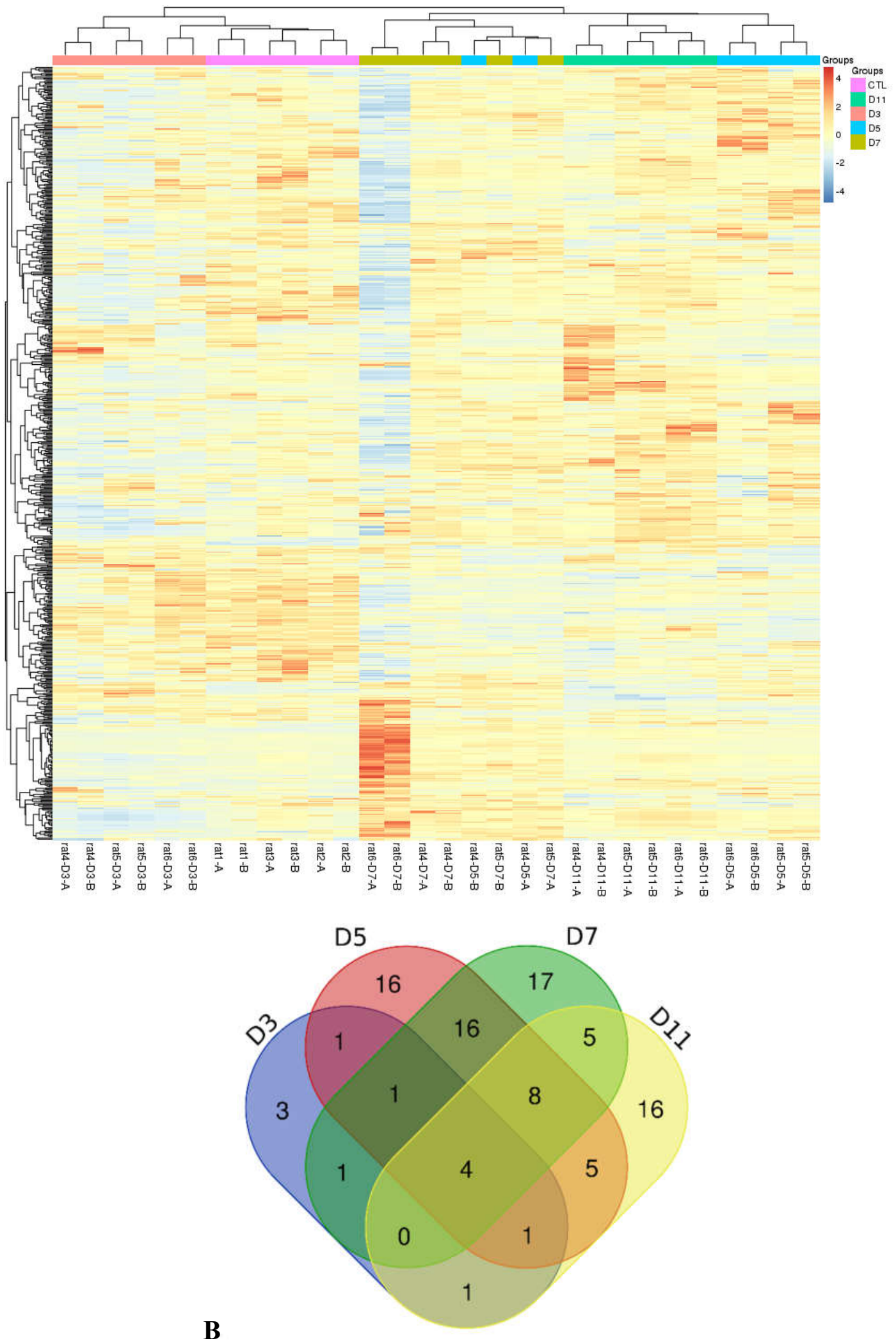

Fig. 3 Statistical analysis of the urine proteome of W256 rats. A) Hierarchical clustering of the 663 proteins from 
the 15 samples (twelve subjects in the tumor-bearing group and three in the control group) at four time points. Lines represent proteins, and the colors correlate with their abundance (red indicates more abundant; blue indicates less abundant). B) The Venn diagram of the differential proteins identified at days 3, 5,7and 11.

Table 1 . Differential urinary proteins in W256 model.

\begin{tabular}{|c|c|c|c|c|c|c|c|c|c|c|c|}
\hline \multirow[t]{2}{*}{ Accession } & \multirow[t]{2}{*}{ Protein name } & \multirow[t]{2}{*}{ Trend } & \multirow[b]{2}{*}{ D3 } & \multicolumn{2}{|c|}{ Fold change } & \multirow[b]{2}{*}{ D11 } & \multirow[t]{2}{*}{$P$ value } & \multicolumn{3}{|c|}{ Reported to be related to } & \multirow{2}{*}{$\begin{array}{c}\text { Reported to be related to other } \\
\text { diseases }\end{array}$} \\
\hline & & & & D5 & D7 & & & & & & \\
\hline P61769 & $\begin{array}{l}\text { Beta-2-microglobulin } \\
\text { (B2MG) }\end{array}$ & $\uparrow$ & 2.58 & 2.98 & 5.48 & 3.63 & 0.0082 & & serum $^{[15]}$ & & \\
\hline P19320 & $\begin{array}{l}\text { Vascular cell adhesion } \\
\text { protein } 1 \text { (VCAM1) }\end{array}$ & $\uparrow$ & 2.19 & 2.92 & 2.58 & 2.27 & 0.075 & & serum $^{[16]}$ & & atherosclerosis $^{[17]}$ \\
\hline P01891 & $\begin{array}{l}\text { Class I histocompatibility } \\
\text { antigen (HA11) }\end{array}$ & $\uparrow$ & 2.43 & 3.45 & 3.43 & 3.29 & $<0.00010$ & & & & \\
\hline Q08380 & $\begin{array}{l}\text { Galectin-3-binding protein } \\
\text { (LG3BP) }\end{array}$ & $\uparrow$ & 4.40 & 4.09 & 2.24 & 1.94 & 0.0001 & & serum $^{[18,19]}$ & & \\
\hline P0C0L4 & Complement $\mathrm{C} 4 \quad(\mathrm{CO} 4)$ & $\uparrow$ & 2.59 & 2.80 & 2.92 & - & 0.0013 & serum & (biomaker) & {$[20,21]$} & \\
\hline P01833 & $\begin{array}{l}\text { Polymeric immunoglobulin } \\
\text { receptor (PIgR) }\end{array}$ & $\uparrow$ & 1.78 & 1.84 & - & 1.56 & 0.00019 & serum & (biomaker) & {$[22]$} & nasopharyngeal carcinoma ${ }^{[23]}$ \\
\hline Q9H008 & $\begin{array}{l}\text { Phospholysine } \\
\text { phosphohistidine inorganic } \\
\text { pyrophosphate phosphatase } \\
\text { (LHPP) }\end{array}$ & $\uparrow$ & - & 1.68 & 2.64 & 1.77 & 0.083 & serum & (biomaker) & {$[24]$} & cervical cancer $^{[25]}$ \\
\hline Q13228 & $\begin{array}{l}\text { Selenium-binding protein } \\
1 \text { (SBP1) }\end{array}$ & $\downarrow$ & - & 0.15 & 0.15 & 0.05 & 0.009 & tissue & (biomaker) & {$[26]$} & prostate cancer $^{[27]}$ \\
\hline P40925 & $\begin{array}{l}\text { Malate dehydrogenase, } \\
\text { cytoplasmic }(\mathrm{MDHC})\end{array}$ & $\downarrow$ & - & 0.14 & 0.46 & 0.38 & 0.0028 & & & & \\
\hline P06733 & Alpha-enolase (ENOA) & $\downarrow$ & - & 0.28 & 0.43 & 0.52 & 0.0016 & tissue & (biomaker) & {$[28]$} & non-small cell lung cancer ${ }^{[29]}$ \\
\hline O75874 & $\begin{array}{l}\text { Isocitrate dehydrogenase } \\
\text { [NADP] cytoplasmic (IDH) }\end{array}$ & $\downarrow$ & - & 0.07 & 0.14 & 0.28 & 0.00042 & & & & \\
\hline P02774 & $\begin{array}{l}\text { Vitamin D-binding protein } \\
\text { (VTDB) }\end{array}$ & $\downarrow$ & - & 0.50 & 0.52 & 0.41 & 0.017 & & & & $\begin{array}{l}\text { lung cancer }{ }^{[30]} \text {, colorectal } \\
\text { cancer }^{[31]}\end{array}$ \\
\hline P07911 & Uromodulin(UROM) & $\downarrow$ & - & 0.50 & 0.61 & 0.32 & 0.012 & & & & \\
\hline P09467 & $\begin{array}{l}\text { Fructose-1,6-bisphosphatase } \\
1 \text { (F16P1) }\end{array}$ & $\downarrow$ & - & 0.17 & 0.20 & 0.32 & 0.00044 & tissue & (biomaker) & {$[32]$} & \\
\hline P02763 & $\begin{array}{l}\text { Alpha-1-acid glycoprotein } \\
\text { (A1AG) }\end{array}$ & $\uparrow$ & 1.82 & 1.58 & - & - & 0.00017 & serum & (biomaker) & {$[33]$} & bladder $^{[34]}$, lung ${ }^{[35]}$ \\
\hline P20472 & Parvalbumin alpha (PRVA) & $\uparrow$ & 2.67 & - & 3.33 & - & 0.017 & & & & \\
\hline P20062 & Transcobalamin-2 (TCII) & $\downarrow$ & 0.53 & - & - & 0.50 & 0.042 & & & & \\
\hline
\end{tabular}




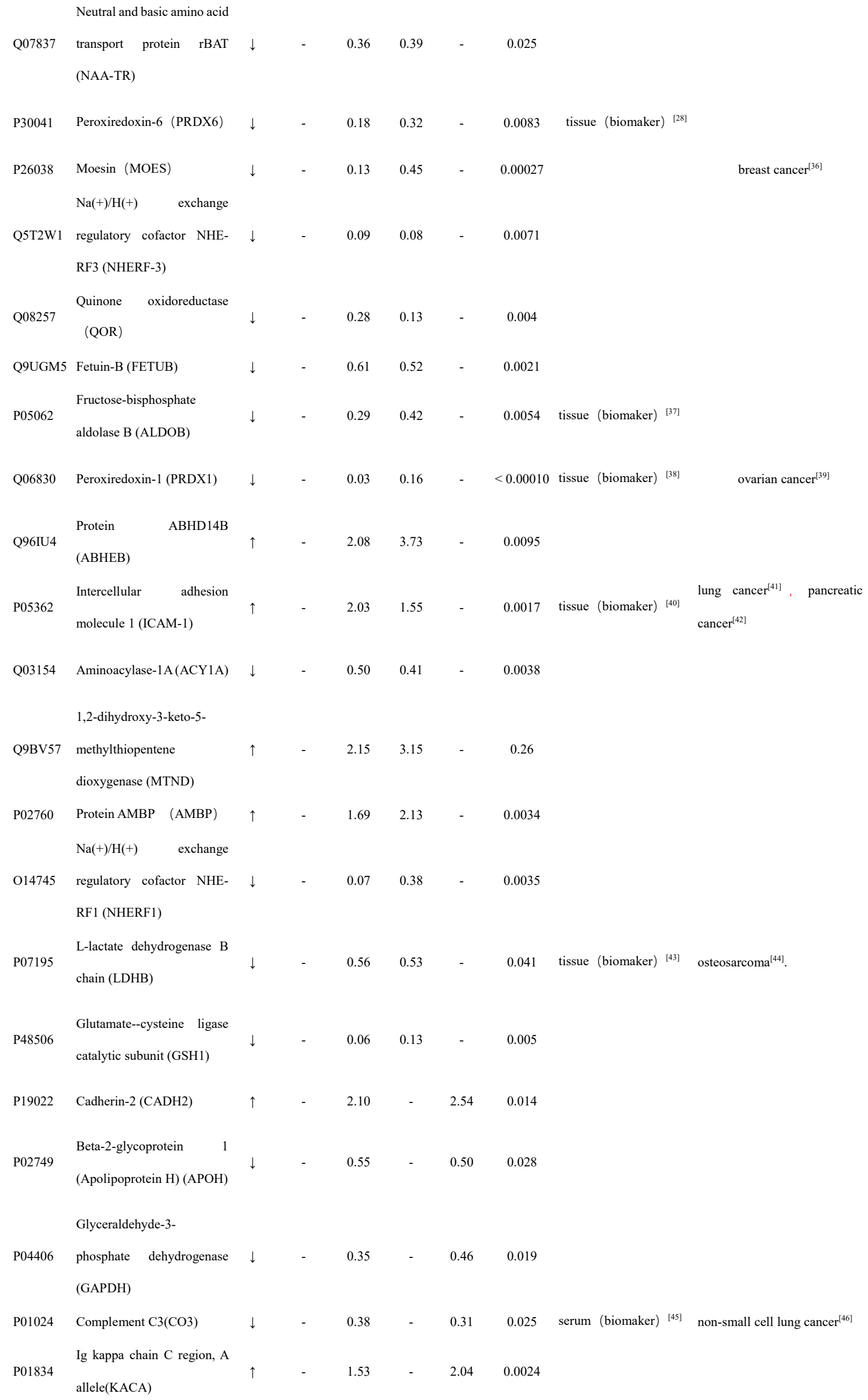




\begin{tabular}{|c|c|c|c|c|c|c|c|c|c|}
\hline P60174 & $\begin{array}{l}\text { Triosephosphate } \\
\text { isomerase(TPIS) }\end{array}$ & $\downarrow$ & - & - & 0.61 & 0.46 & 0.0027 & tissue $^{[47]}$ & \\
\hline O95336 & $\begin{array}{l}\text { 6-phosphogluconolactonase } \\
\text { (6PGL) }\end{array}$ & $\uparrow$ & - & - & 1.54 & 1.58 & 0.057 & & $\begin{array}{l}\text { breast cancer }{ }^{[48]} \text { non-small cell } \\
\text { lung } \text { cancer }^{[49]}, \quad \text { ovarian } \\
\text { cancer }^{[50]}\end{array}$ \\
\hline O43895 & $\begin{array}{l}\text { Xaa-Pro aminopeptidase } 2 \\
\text { (XPP2) }\end{array}$ & $\downarrow$ & - & - & 0.39 & 0.32 & 0.0058 & & \\
\hline P53634 & $\begin{array}{l}\text { Dipeptidyl peptidase } 1 \\
\text { (CATC) }\end{array}$ & $\downarrow$ & - & - & 0.67 & 0.45 & 0.18 & & \\
\hline P10253 & $\begin{array}{l}\text { Lysosomal alpha- } \\
\text { glucosidase (LYAG) }\end{array}$ & $\downarrow$ & - & - & 0.57 & 0.18 & 0.0023 & & \\
\hline P09668 & Pro-cathepsin H(CATH) & $\downarrow$ & 0.50 & - & - & - & 0.1 & & \\
\hline P04083 & Annexin A1 (ANXA1) & $\uparrow$ & 1.82 & - & - & - & 0.13 & tissue (biomaker) ${ }^{[51]}$ & cholangiocarcinoma $^{[52]}$ \\
\hline Q9UMR5 & $\begin{array}{l}\text { Lysosomal thioesterase } \\
\text { (PPT2) }\end{array}$ & $\downarrow$ & 0.64 & - & - & - & 0.12 & & \\
\hline P22392 & $\begin{array}{l}\text { Nucleoside diphosphate } \\
\text { kinase B (NDKB) }\end{array}$ & $\downarrow$ & - & 0.52 & - & - & 0.054 & & \\
\hline P20142 & $\begin{array}{l}\text { Gastricsin (Pepsinogen } \\
\text { C)(PEPC) }\end{array}$ & $\uparrow$ & - & 1.78 & - & - & 0.37 & & gastric carcinoma $^{[53]}$ \\
\hline P01019 & Angiotensinogen (ANGT) & $\uparrow$ & - & 1.76 & - & - & 0.007 & serum $^{[54]}$ & \\
\hline P01133 & $\begin{array}{l}\text { Pro-epidermal growth factor } \\
\text { (EGF) }\end{array}$ & $\downarrow$ & - & 0.57 & - & - & 0.025 & & \\
\hline Q8IV08 & Phospholipase D3 (PLD3) & $\downarrow$ & - & 0.56 & - & - & 0.25 & & \\
\hline Q5KU26 & Collectin-12 (COL12) & $\uparrow$ & - & 1.89 & - & - & 0.11 & & \\
\hline P05155 & $\begin{array}{l}\text { Plasma protease } \mathrm{C} 1 \text { inhibitor } \\
\text { (IC1) }\end{array}$ & $\uparrow$ & - & 2.03 & - & - & 0.22 & & ovarian cancer ${ }^{[55]}$ \\
\hline P05186 & $\begin{array}{l}\text { Alkaline phosphatase, } \\
\text { tissue-nonspecific isozyme } \\
\text { (PPBT) }\end{array}$ & $\downarrow$ & - & 0.21 & - & - & 0.063 & & \\
\hline Q96AP7 & $\begin{array}{l}\text { Endothelial cell-selective } \\
\text { adhesion molecule(ESAM) }\end{array}$ & $\uparrow$ & - & 1.53 & - & - & 0.019 & & \\
\hline Р00749 & $\begin{array}{l}\text { Urokinase-type } \\
\text { plasminogen } \\
\text { activator(UROK) }\end{array}$ & $\downarrow$ & - & 0.52 & - & - & 0.00045 & tissue $^{[56,57]}$ & \\
\hline P07998 & $\begin{array}{l}\text { Ribonuclease pancreatic } \\
\text { gamma-type (RNS1G) }\end{array}$ & $\downarrow$ & - & 0.22 & - & - & 0.02 & & \\
\hline P01034 & Cystatin-C (CYTC) & $\uparrow$ & - & 1.79 & - & - & 0.0054 & tissue $^{[58]}$ & $\mathrm{CCA}^{[59]}$ \\
\hline P18669 & $\begin{array}{l}\text { Phosphoglycerate mutase } 1 \\
\text { (PGAM1) }\end{array}$ & $\downarrow$ & - & 0.16 & - & - & 0.0055 & & \\
\hline
\end{tabular}




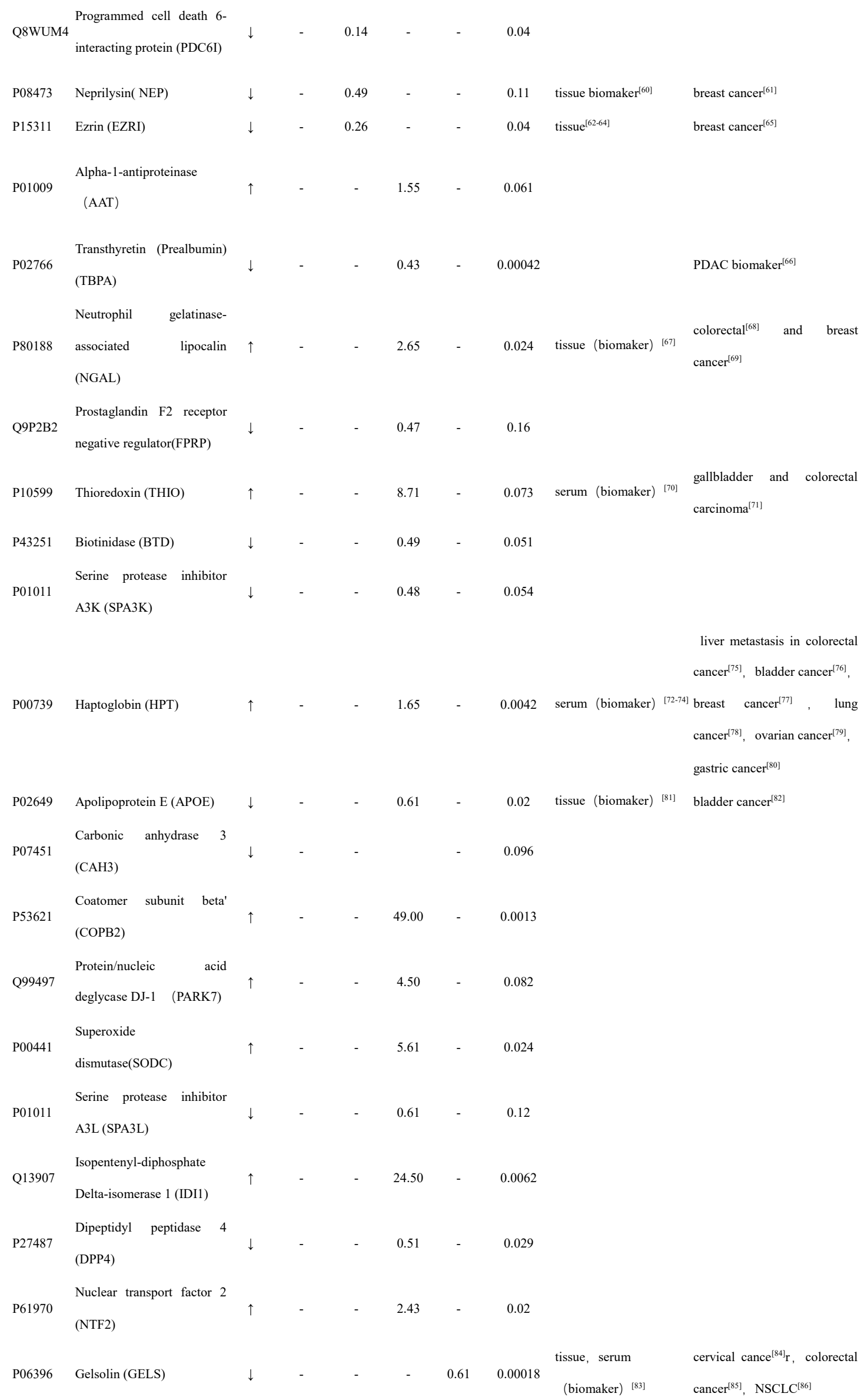




\begin{tabular}{|c|c|c|c|c|c|c|c|c|c|}
\hline Q9UHL4 & $\begin{array}{l}\text { Dipeptidyl peptidase } 2 \\
\text { (DPP2) }\end{array}$ & $\downarrow$ & - & - & - & 0.65 & 0.027 & & $\operatorname{CLL}^{[87]}$ \\
\hline P26718 & $\begin{array}{l}\text { NKG2-D type II integral } \\
\text { membrane protein(NKG2D) }\end{array}$ & $\uparrow$ & - & - & - & 5.80 & 0.0083 & & \\
\hline Q8WW52 & Protein FAM151A(F151A) & $\downarrow$ & - & - & - & 0.58 & 0.091 & & \\
\hline O14773 & $\begin{array}{l}\text { Tripeptidyl-peptidase } 1 \\
\text { (TPP1) }\end{array}$ & $\downarrow$ & - & - & - & 0.35 & 0.016 & & \\
\hline P01859 & $\begin{array}{l}\text { Ig gamma-2A chain } \mathrm{C} \\
\text { region(IGG2A) }\end{array}$ & $\uparrow$ & - & - & - & 2.75 & $<0.00010$ & & \\
\hline P14550 & $\begin{array}{l}\text { Alcohol } \\
\text { dehydrogenase(AK1A1) }\end{array}$ & $\downarrow$ & - & - & - & 0.48 & 0.31 & serum (biomaker) ${ }^{[88]}$ & $\begin{array}{l}\text { endometrial } \text { cancer }^{[89]} \\
\text { pancreatic cancer } \\
\end{array}$ \\
\hline P02743 & $\begin{array}{l}\text { Serum amyloid P- } \\
\text { component (SAMP) }\end{array}$ & $\downarrow$ & - & - & - & 0.59 & 0.39 & serum (biomaker) ${ }^{[18]}$ & $\operatorname{NSCL}^{[91]}$, lung cancer ${ }^{[92]}$ \\
\hline O00244 & $\begin{array}{l}\text { Copper transport protein } \\
\text { (ATOX1) }\end{array}$ & $\uparrow$ & - & - & - & 2.09 & 0.18 & & \\
\hline P05937 & $\begin{array}{l}\text { Calbindin } \quad \text { (Calbindin } \\
\text { D28)(CALB1) }\end{array}$ & $\downarrow$ & - & - & - & 0.25 & 0.055 & & lung cancer ${ }^{[93]}$ \\
\hline P07686 & $\begin{array}{l}\text { Beta-hexosaminidase } \\
\text { subunit beta (HEXB) }\end{array}$ & $\downarrow$ & - & - & - & 0.42 & 0.019 & & \\
\hline P06865 & $\begin{array}{l}\text { Beta-hexosaminidase } \\
\text { subunit alpha (HEXA) }\end{array}$ & $\downarrow$ & - & - & - & 0.40 & 0.053 & & \\
\hline P08571 & $\begin{array}{l}\text { Monocyte differentiation } \\
\text { antigen CD14 (CD14) }\end{array}$ & $\uparrow$ & - & - & - & 1.91 & 0.0025 & serum (biomaker) ${ }^{[94]}$ & \\
\hline O75882 & Attractin (ATRN) & $\downarrow$ & - & - & - & 0.51 & 0.089 & & malignant astrocytoma $^{[95]}$ \\
\hline Q9Y646 & $\begin{array}{l}\text { Carboxypeptidase } \\
\text { (CBPQ) }\end{array}$ & $\downarrow$ & - & - & - & 0.62 & 0.0027 & & \\
\hline P04066 & $\begin{array}{l}\text { Tissue alpha-L-fucosidase } \\
\text { (AFU) }\end{array}$ & $\downarrow$ & - & - & - & 0.36 & 0.00031 & serum (biomaker) ${ }^{[96]}$ & \\
\hline
\end{tabular}

\subsection{Comparison of urinary proteins in different tumor models}

The differential urinary proteins of four W256 tumor models (liver tumor model, lung metastasis model, intracerebral tumor model, and subcutaneous model) at all time points were compared and shown in Venn diagram (Fig.4). 


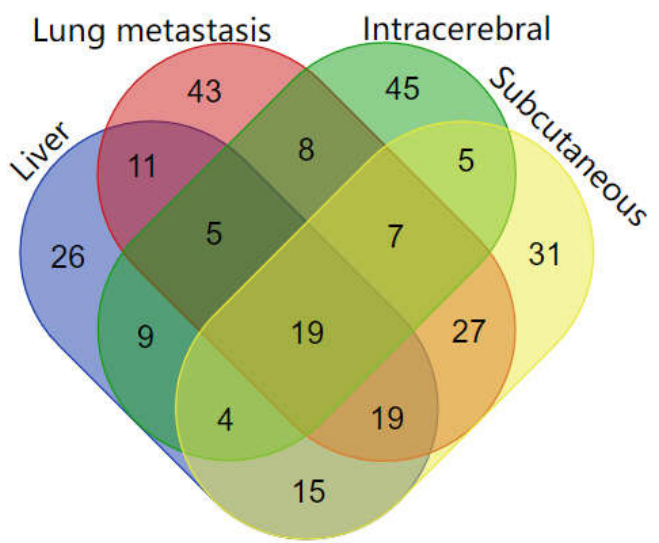

Fig. 4. The overlapping differential proteins in urine samples of the four different W256 tumor models.

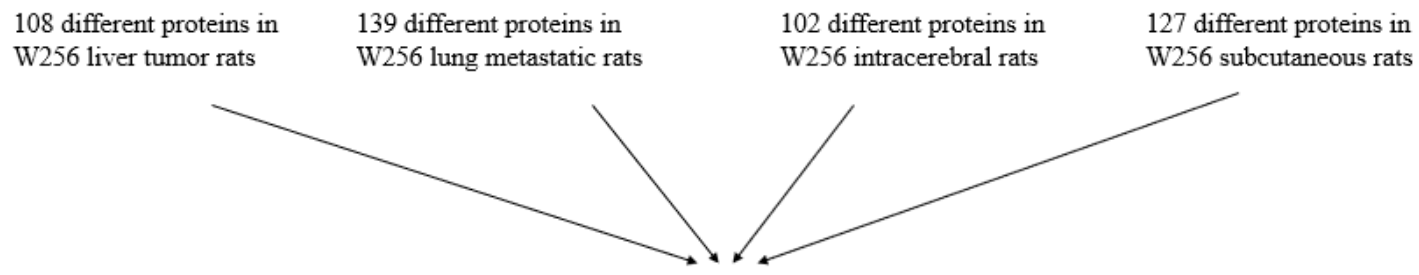

26 different proteins identified specifically in W256 liver tumor rats

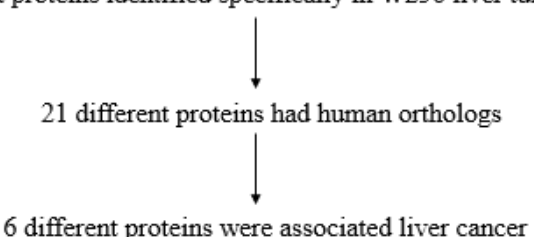

Fig. 5. The comparison procedure of urinary proteins differentially expressed in the four models.

The result indicates that the same tumor cell grown in different organs can be reflected in differential urinary proteins. It can be seen from the Venn diagram that each model had a different number of unique differential urinary proteins. The $26,43,45$, and 31 unique differential proteins were identified in the liver tumor model, the lung metastasis model, the intracerebral tumor model, and the subcutaneous model, respectively.

Twenty-one differential proteins had human orthologs were specially identified in W256 liver tumor model compared with the other three models. The comparison procedure is presented in Figure 5. Six of the 21 proteins (SAMP, LDHB, AFU, UROK, PRDX6, and PRDX1) had been reported to be associated with liver cancer. They were identified at the tumor development stages (D5, D7 and D13). (1) Serum amyloid P component (SAMP) is a candidate biomarker for HCC development in cirrhotic patients who were infected $\mathrm{HCV}{ }^{[18]}$. (2) The expression of Lactate dehydrogenase B (LDHB) is a valuable prognostic biomarker for HCC. When the expression of LDHB becomes low, it suggests unfavorable survival outcomes ${ }^{[43]}$. (3) Alpha-1-fucosidase (AFU) is a lysosomal enzyme present in all mammalian cells and it has been proposed as a promising tumor marker since many studies reported increased AFU serum levels in patients with cirrhosis and HCC ${ }^{[96]}$. (4) Urokinase-type plasminogen activator(UROK) expression may be a potent therapeutic target of HCC ${ }^{[97]}$. (5) Peroxiredoxin 6 (PRDX6) may be a candidate biomarker for early HCC diagnosis ${ }^{[28]}$. (6) Peroxiredoxin 1 (PRDX1) is overexpressed in the tumor tissues of liver cancer and it also can predict poor prognosis for overall survival independently ${ }^{[38]}$. 
Among the 21 differential proteins, the remaining 15 proteins have not been reported as biomarkers of liver cancer. However, some of them were detectable at two time points. For example, it is reported that overexpression of cathepsin $\mathrm{H}(\mathrm{CATH})$ is related to several pathological states including carcinoma and melanoma ${ }^{[98-100]}$. Protein AMBP, a liver-specific precursor, is also a precursor of heme-binding protein that counteracts the disruption of free hemoglobin ${ }^{[101,102]}$. Cadherin-2 (CADH2) is called mesenchymal cadherin in carcinomas which play a role in epithelial-to-mesenchymal transition, and this process was considered to contribute to carcinoma progression [103,104]. Endothelial cell-selective adhesion molecule (ESAM), a member of the immunoglobulin receptor family, mediates homophilic interactions between endothelial cells. It suggests that ESAM has a special functional role in pathological angiogenic processes such as tumor growth ${ }^{[105]}$. Phosphoglycerate mutase 1 (PGAM1) is an important glycolytic enzyme that regulates many important biological processes, such as glycolysis, pentose phosphate pathway and serine biosynthesis in cancer cells ${ }^{[106]}$. The different functions of these proteins might be able to help distinguish the liver tumor and the tumors of other organs. These proteins may have potential for diagnosis and treatment of liver cancer in the future.

Among the overlapping proteins of these four models, it can be found that (1) 17 proteins had human orthologs can be detected in all models; (2) Most of the overlapping proteins reappear in more than two models in different combinations (Fig.4). One of the reasons for the appearance of these common proteins may be due to the same cells injected in all models; (3) Among the common proteins, 24 differential proteins had been reported to be associated with liver cancer, and some proteins had been identified as biomarkers in a variety of tumors; (4) The different combinations of the common proteins are also important to diagnosis. Because it is difficult to diagnose the type of tumor by using a single biomarker, thereby the panel of biomarkers is more accurate and reliable. Above all, the comparison results show that the growth of tumors in different organs has both commonality and individual difference. The urinary proteins have the potential to distinguish same tumor cell grown in different organs.

\subsection{Functional analysis of differential proteins}

In the W256 liver tumor model, the functional analysis of differential proteins at days 3, 5, 7 and 11 consisted of categorizing the biological processes, diseases, and functions using DAVID (Fig. 6). Ninetyeight differential proteins were annotated. In the biological processes, the innate immune response, retina homeostasis, response to drugs, negative regulation of endopeptidase activity, membrane to membrane docking, leukocyte cell-cell adhesion, complement activation classical pathway, and glycolytic process were significantly changed. At day 3, the innate immune response was the first to respond to the tumor cells. At day 5 and day 7, with the development of tumors in vivo, the glycolytic process, complement activation classical pathway, carbohydrate metabolic process, glutathione metabolic process, leukocyte adhesion, membrane to membrane docking, establishment of the endothelial barrier, and negative regulation of endopeptidase activity began to respond to the tumor changes. At day 11, the tumor grew further in the body, and the necrosis of some tissues caused phagocytosis recognition. The need for nutrients made some biological processes that were similar to the previous time-points continue. (Fig. $6 \mathrm{~A})$. In the cellular component, most of the differential proteins were in the extracellular exosome, extracellular space, MHC class I protein complex, blood microparticle, and extracellular region. They were changed in all the time-points. A small number of differential proteins come from organelles (Fig. $6 \mathrm{~B})$. In the molecular function category, endopeptidase inhibitor activity, identical protein binding, peroxiredoxin activity, and NAD binding were overrepresented. These biological processes were associated with neoplastic progression (Fig. 6C). From these analyses, it can be seen that these proteins 
caused these changes and their sources. This further confirmed that the changes in urinary protein come from the body's response to the tumor cells. When the W256 cells entered the body, they caused an innate immune response. With the tumor development, the tumor cells further evaded or counterattacked the immune system through various pathways ${ }^{[107]}$.

The IPA analysis yielded several results. In the canonical pathway, FXR/RXR activation, gluconeogenesis I, glycolysis I, LXR/RXR activation, acute phase response signaling, allograft rejection signaling, phagosome maturation, OX40 signaling pathway, Cdc42 signaling and NRF2-mediated oxidative stress response showed the most marked changes. It was demonstrated that LXR/RXR activation, acute-phase response signaling, IL-12 signaling, production of nitric oxide and reactive oxygen species in macrophages, and the complement system were significantly enriched during tumor progression ${ }^{[11]}$. Gluconeogenesis I and glycolysis I also demonstrated the process of tumor development because of the increased glucose flux compared to normal tissue that is a common trait of human malignancies ${ }^{[108]}$. Some similar pathways have changed compared to previous experiments in which W256 cells were injected at other sites. The common pathways included acute-phase response signaling, LXR/RXR activation IL-12 signaling, and the complement system. The W256 tumor-bearing rat model has been previously used to study cancer-induced cachexia. Cachexia was characterized by weight loss after tumor cell inoculation ${ }^{[109,110]}$. This study also demonstrated results consistent with previous studies (Fig. 7).

A

\section{Biological Process}

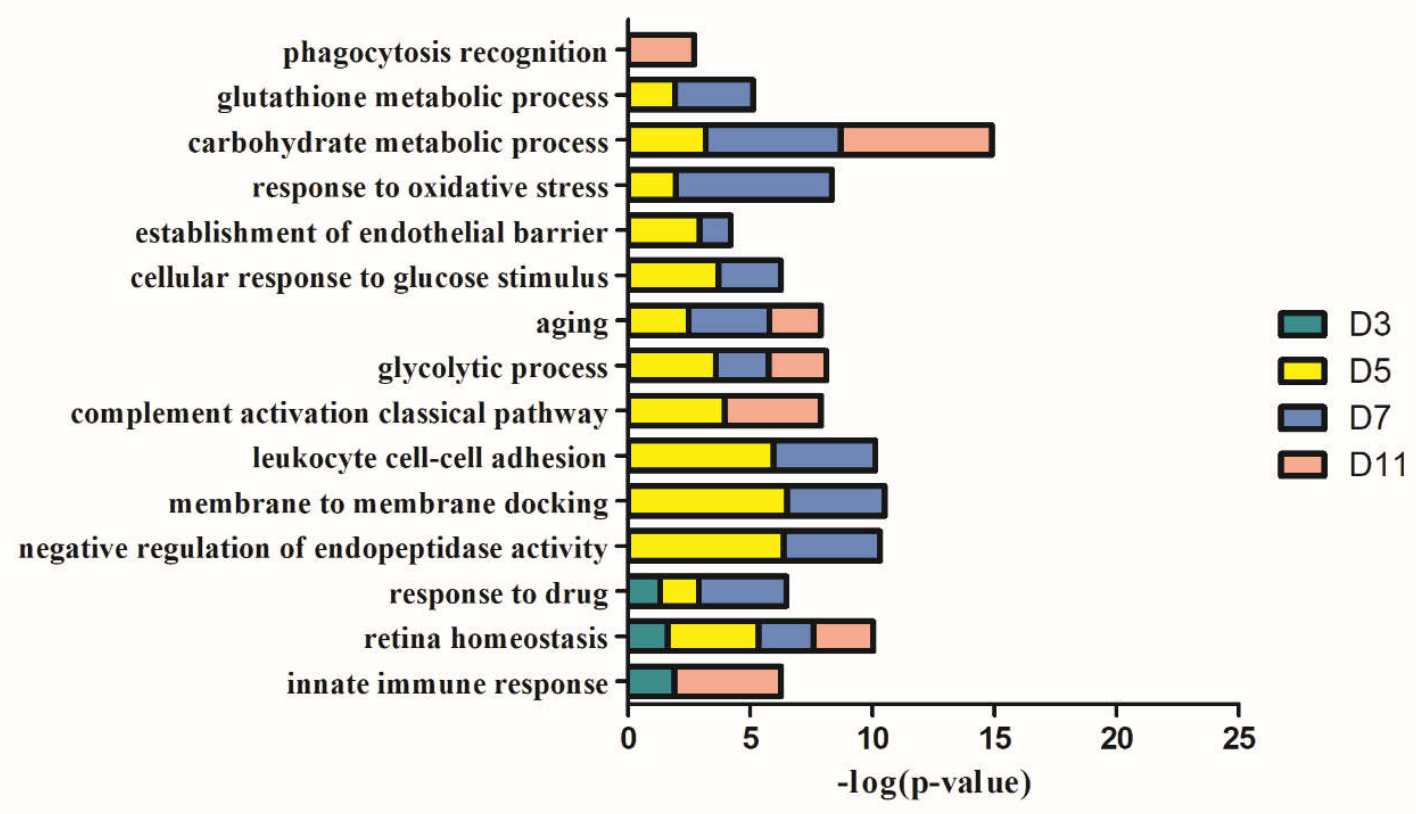




\section{Cellular Component}

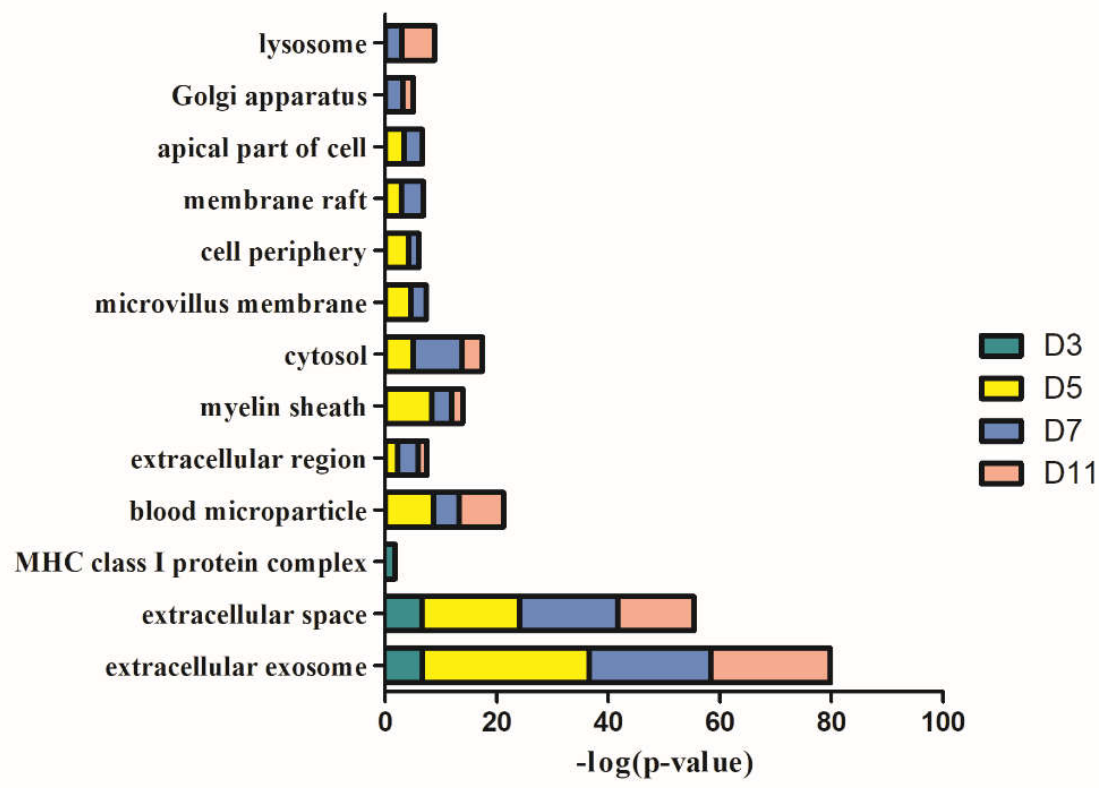

B

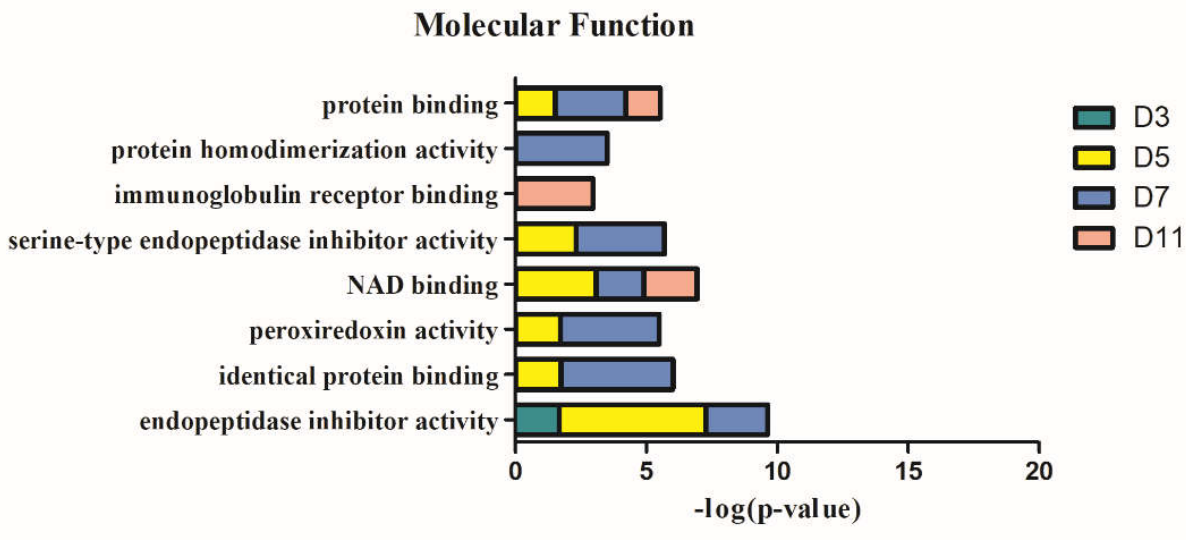

C

Fig. 6. Functional analysis of differential proteins at days 3, 5, 7 and 11 in W256 model. A) Biological process; B) Cellular component; C) Molecular function. 


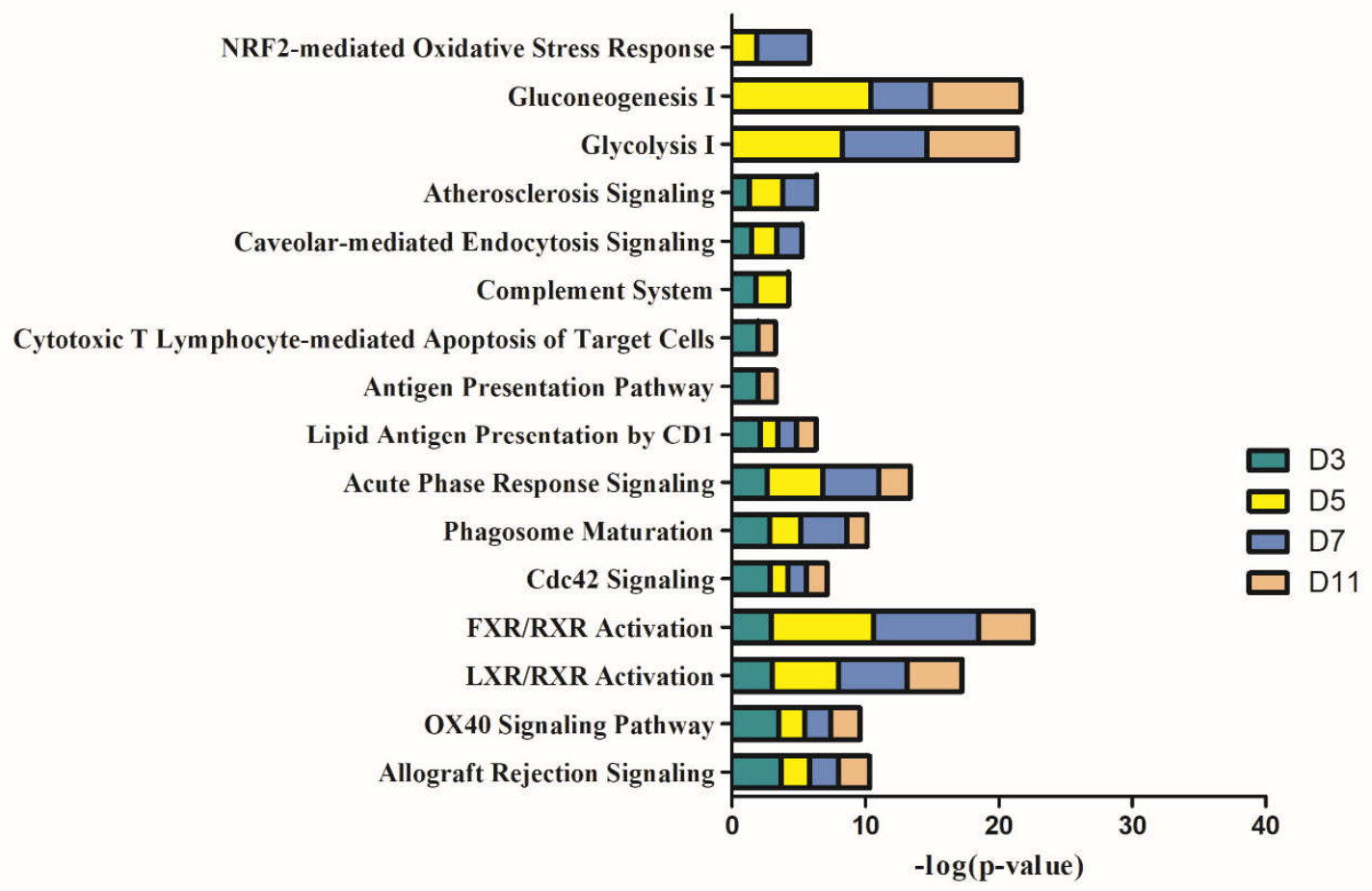

Fig. 7. IPA analysis of differential proteins at days 3, 5, 7 and 11 in W256 model.

Figure 8 shows the comparison of biological processes of the liver tumor model with other models at early stages based on the data obtained from the studies of our laboratory published before ${ }^{[11,111,112]}$. The urinary proteins of different W256 models reflect different biological processes, suggesting that the biological processes of the same tumor cell grown in different organs may be different. In the early stages of all the models, the biological processes are very different. In the liver tumor model, the biological processes mainly reflect the immune response and metabolism. It may be due to that liver is a central organ for homeostasis and carries out a wide range of functions, including metabolism, glycogen storage, drug detoxification, production of various serum proteins, and bile secretion ${ }^{[113]}$. These biological processes are also associated with the functions of the liver. In the subcutaneous model, the biological processes are the primary response to various nutrients and ions. In the intracerebral tumor model, recognition and migration of cells in the biological processes are particularly significant. In the lung metastasis model, the biological processes include epithelial cell differentiation, regulation of immune system process, complement activation, classical pathway, ERK1 and ERK2 cascade, inflammatory response, etc. A large number of different early biological processes exist in the lung metastasis model for the reason that the differential proteins in the early stage are more than those of the other three models. 
Liver

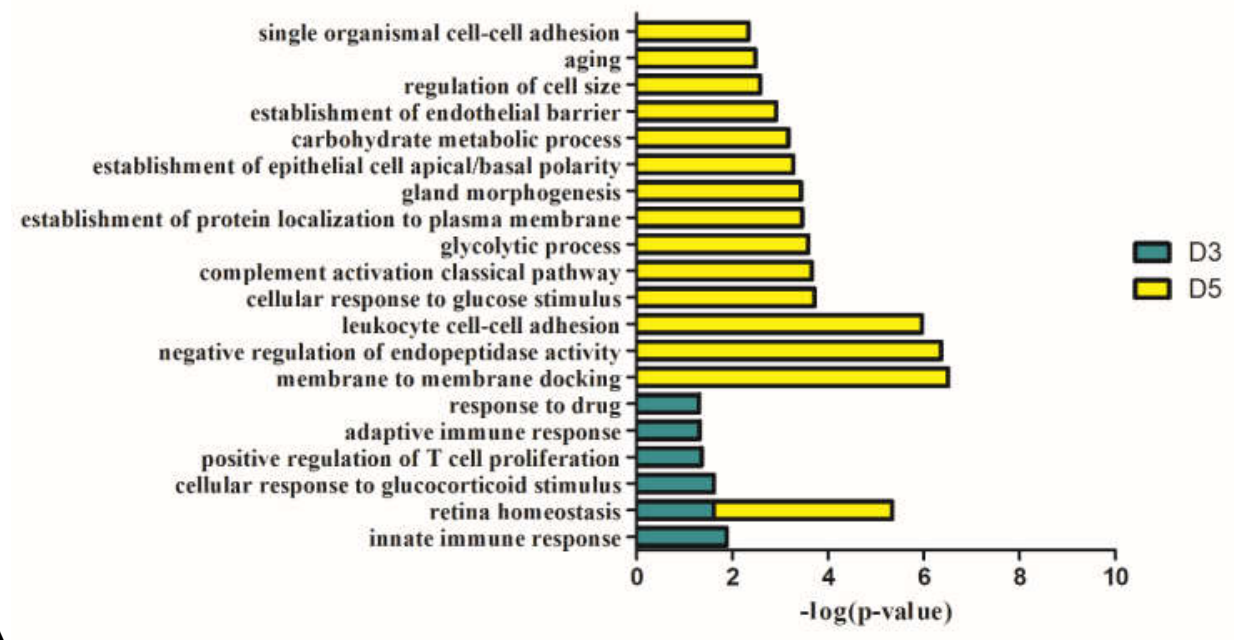

\section{Subcutaneous}

regulation of multicellular organism growth response to copper ion phagocytosis recognition vasodilation response to estradio response to magnesium ion complement activation removal of superoxide radicals positive regulation of superoxide anion generation response to nutrient response to nutrient levels response to organic substance retina homeostasis aging complement activation classical pathway negative regulation of endopeptidase activity response to drug -
proteolysis innate immune response acute-phase response -

\section{B}

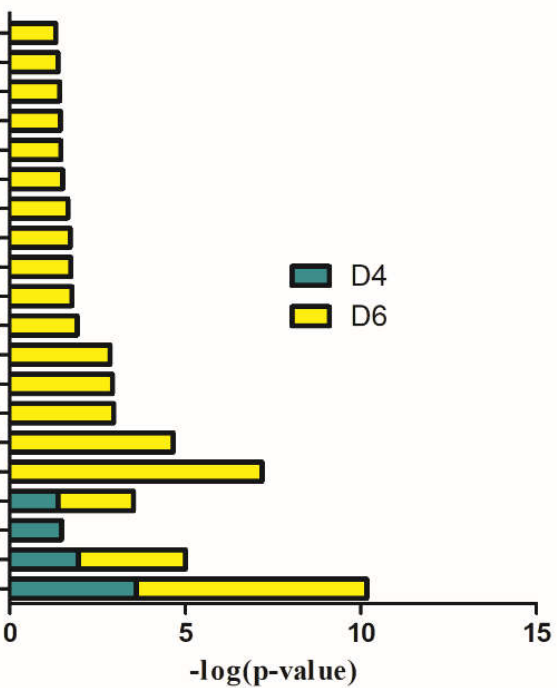

\section{Intracerebral}

positive regulation of endocytosis tissue homeostasis negative regulation of proteasomal ubiquitin-dependent protein catabolic process negative regulation of neuron apoptotic process cell migration involved in sprouting angiogenesis
cell recognition response to molecule of bacterial origi response to drug cell adhesion 口D5 ponse to organic substanc inflammatory response aging
embryonic cranial skeleton morphogenesis
retina homeostasis retina homeostasis in utero embryonic developmente inulation of cell migration positive regulation of cell migration
cellular response to lipopolysaccharide

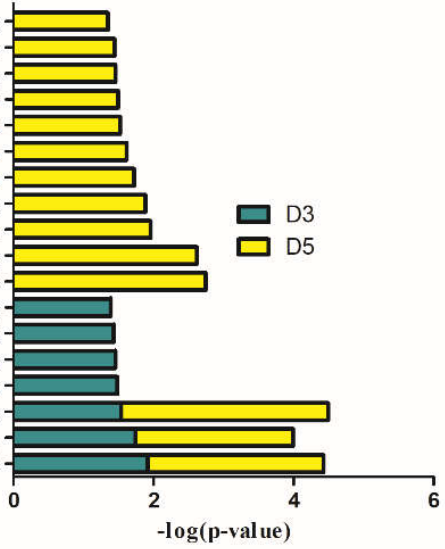




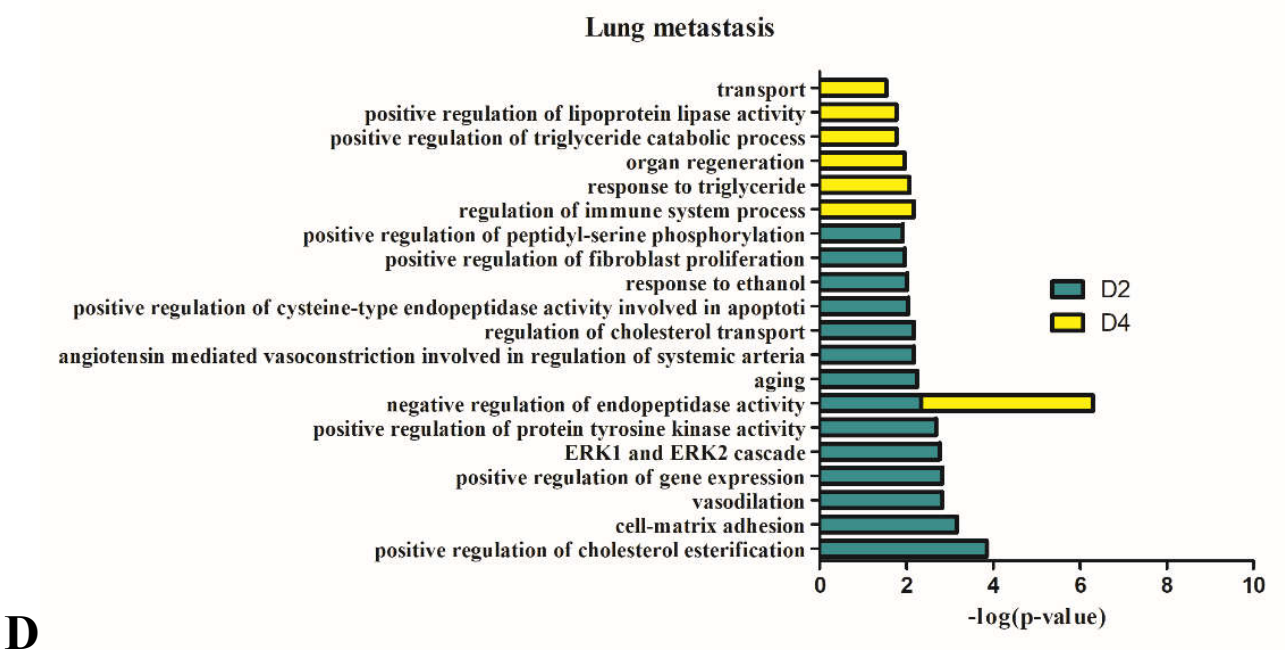

Fig. 8. The analysis of the early stages of biological processes in different W256 models. A) The liver tumor model; B) the subcutaneous model; C) the intracerebral tumor model; D) the lung metastasis model. All the early biological processes are shown above. There are 34 early biological processes in the W256 lung metastasis model. For the convenience of comparison, the same number of biological processes as the W256 liver tumor model was selected according to p-value.

\subsection{Analysis of differential proteins}

In the W256 liver tumor model, the urinary proteins changed significantly after the tumor cells were implanted in the rats. Twelve proteins at day 3 changed significantly before the obvious pathological appearance, and fifty-two proteins changed at day 5. At day 3, nine of these proteins, LG3BP, PRVA, CO4, B2MG, HA11, VCAM1, ANXA1, A1AG, and PIGR, all were upregulated in liver cancer and other diseases in the serum or tissue. B2MG, VCAM1, HA11, and LG3BP were detected at all four time-points, and the other two proteins, CO4 (day 3, day 5 and day 7) and PIGR (day 3, day 5 and day 11), were found at three different time-points. A1 AG continuously changed at day 3 and day 5. Galectin-3-binding protein (LG3BP) is a secreted glycoprotein that has an affinity for galectins and extracellular matrix proteins, and it can also interact and regulate cell adhesion ${ }^{[15]}$. It has been reported that LG3BP is expressed at high levels in various infectious and malignant diseases, such as HCV and HCC ${ }^{[1,114]}$. LG3BP was considered a poor prognosis biomarker in different types of malignancy ${ }^{[115]}$. Complement $\mathrm{C} 4$ (CO4) was reported as a potential biomarker to detect HCC in serum samples [20,21]. Beta-2microglobulin (B2MG) may be used as a serum biomarker in HCV-related chronic liver diseases ${ }^{[116] . ~}$ Vascular cell adhesion protein 1 (VCAM1) is closely related to the severity of the underlying liver disease ${ }^{[16]}$. Annexin A1 (ANXA1) is a member of the annexin superfamily proteins that can cause the pathological consequence and sequelae of many human diseases, and it can be used as a prognosis biomarker and a potential therapeutic target in $\mathrm{HCC}^{[51]}$. Alpha-1-acid glycoprotein (A1AG) was reported to be a potential biomarker in HCC patients ${ }^{[33]}$. Polymeric immunoglobulin receptor (PIGR) is one of the Fc receptor family members and is an important component of the mucosal immune system ${ }^{[22]}$. It has been proven to be a potential clinical target with the ability to promote cancer malignancy in HCC ${ }^{[117]}$. Of the other proteins, the fold change of parvalbumin alpha (PRVA) ranked second among the significantly upregulated proteins, and there were three downregulated proteins, lysosomal thioesterase (PPT2), transcobalamin-2 (TCII), pro-cathepsin H (CATH) and Class I histocompatibility antigen (HA11). Although there is a lack of reports associating them with liver cancer or other liver diseases, 
they may play an important role in the early stage of liver cancer.

At day 5, in addition to the proteins mentioned above, five of the upregulated proteins (ICAM1, CYTC, LHPP, A1 AG, and ANGT) and ten of the downregulated proteins (LDHB, UROK, CO3, ALDOB, ENOA, EZRI, PRDX6, F16P1, SBP1, and PRDX1) were reported to be associated with liver cancer. Intercellular adhesion molecule 1 (ICAM1) belongs to the immunoglobulin superfamily and it has diagnostic significance in different kinds of HCC, such as AFP-negative or suspected HCC ${ }^{40]}$. The expression of Cystatin C (CYTC) is higher in primary hepatic carcinoma than the control both at the tissue level and serum leve ${ }^{[58]}$. There is a low rate of overall survival when the expression of histidine phosphatase (LHPP), a tumor suppressor, is reduced in patients with hepatocellular carcinoma ${ }^{[24]}$. Alpha1-acid glycoprotein (A1AG) was found to be a novel biomarker to distinguish HCC plasma from control plasmas ${ }^{[33]}$. It has been reported that hepatoma is an angiotensinogen (ANGT)-producing tumor ${ }^{[54]}$. Llactate dehydrogenase $\mathrm{B}$ chain (LDHB) is a valuable prognostic biomarker, and low expression suggests poor survival outcomes in HCC patients ${ }^{[43]}$. The Complement $\mathrm{C} 3$ (CO3) detection starts at a very early stage of tumor development, and it may represent a biomarker candidate for liver cancer ${ }^{[45]}$. The downregulation of fructose-bisphosphate aldolase B (ALDOB) suggests a poor prognosis, and it is a prognostic biomarker, especially at the early stage of HCC ${ }^{[37]}$. Alpha-enolase (ENOA) has been reported as biomarkers for HCC ${ }^{[28]}$. Ezrin (EZRI) expression can predict metastasis disease in human primary hepatocellular carcinoma tissue ${ }^{[62]}$. Fructose-1, 6-bisphosphatase 1 (F16P1) and seleniumbinding protein 1 (SBP1) are considered potential biomarkers for prognosis in liver cancer ${ }^{[26,32]}$. Among the top-ranked proteins according to values of their fold change, for example, in the top ten of upregulation (MTND, CADH2, ABHEB, and IC1) and the top ten of downregulation (PGAM1, MDHC, PDC6I, MOES, NHRF3, IDHC, NHRF1, and GSH1), these unreported proteins also have great potential to be used to predict liver cancer. Although no relationship with liver cancer has been established, previous research suggests that they play important roles in other diseases (Table 1).

As the disease progressed, the number of proteins increased significantly at the last two time-points (day7 and day11). The pathological manifestations at these stages were also very obvious. Therefore, protein biomarker candidates were mainly selected at the time-points before pathological changes, especially those proteins that changed continuously, such as LG3BP, B2MG, CO4, VCAM1, HA11, A1AG, and PIGR. Among all differential proteins, several proteins were not only associated with liver cancers but also differentially changed in other cancers, suggesting that it is difficult to distinguish cancer types by relying on one or two protein markers. This may be related to the mechanism of tumor development.

Thus, this study suggests that a panel of urinary differential proteins is an ideal choice to improve the sensitivity and accuracy of early diagnosis for liver cancer.

\section{Conclusion}

Before the obvious pathological changes in the liver tumor model, the urinary differential proteins could be identified. Several differential proteins had been reported to be associated with liver cancer. These findings may provide important information for the early diagnosis of liver cancer. Additionally, the same tumor cell grown in different organs can be reflected in differential urinary proteins.

\section{Author contributions}


Y.Z. and Y.H.Gao. conceived and designed the experiments. Y.Z. and Y.F.Gao. performed the experiments. Y.Z. analyzed the data and wrote the manuscript. All authors approved the final manuscript.

\section{Competing interests}

The authors declare that they have no competing interests.

\section{Acknowledgements}

This research was supported by the National Key Research and Development Program of China (2016 YFC 1306300), Key Basic Research Program of the Ministry of Science and Technology of China (2013FY114100), Beijing Natural Science Foundation (7173264, 7172076), Beijing cooperative construction project (110651103), Beijing Normal University (11100704), and Peking Union Medical College Hospital (2016-2.27). 


\section{Reference}

[1] Chen W, Zheng R, Zhang S, et al. Cancer incidence and mortality in China, 2013[J]. Cancer letters, 2017, 401: 63-71.

[2] Ayuso C, Rimola J, Vilana R, et al. Diagnosis and staging of hepatocellular carcinoma (HCC): current guidelines[J]. European journal of radiology, 2018, 101: 72-81.

[3] Pahwa A, Beckett K, Channual S, et al. Efficacy of the American Association for the Study of Liver Disease and Barcelona criteria for the diagnosis of hepatocellular carcinoma[J]. Abdominal Imaging, 2014, 39(4): 753-760.

[4] Spangenberg H, Thimme R, Blum H. Serum markers of hepatocellular carcinoma[C]. Seminars in liver disease, 2006: 385-390.

[5] Tsuchiya N, Sawada Y, Endo I, et al. Biomarkers for the early diagnosis of hepatocellular carcinoma[J]. World journal of gastroenterology: WJG, 2015, 21(37): 10573.

[6] Gao Y. Urine-an untapped goldmine for biomarker discovery[J]. Sci China Life Sci, 2013, 56(12): 1145-1146.

[7] Wang Y, Chen Y, Zhang Y, et al. Differential ConA-enriched urinary proteome in rat experimental glomerular diseases[J]. Biochemical and biophysical research communications, 2008, 371(3): 385-390.

[8] Yuan Y, Zhang F, Wu J, et al. Urinary candidate biomarker discovery in a rat unilateral ureteral obstruction model[J]. Scientific reports, 2015, 5: 9314.

[9] Zhang F, Ni Y, Yuan Y, et al. Urinary proteome changes were detected earlier than serum biochemical parameters and histopathology changes in a rat thioacetamide-induced hepatic fibrosis model[J]. The FASEB Journal, 2017, 31(1_supplement): 908.17-908.17.

[10] Zhao $\mathrm{M}, \mathrm{Wu} \mathrm{J}, \mathrm{Li} \mathrm{X}$, et al. Urinary candidate biomarkers in an experimental autoimmune myocarditis rat model[J]. Journal of proteomics, 2018, 179: 71-79.

[11] $\mathrm{Wu}$ J, Guo Z, Gao Y. Dynamic changes of urine proteome in a Walker 256 tumor-bearing rat model[J]. Cancer medicine, 2017, 6(11): 2713-2722.

[12] Ni Y, Zhang F, An M, et al. Early candidate biomarkers found from urine of glioblastoma multiforme rat before changes in MRI[J]. Science China Life Sciences, 2018: 1-6.

[13] Wisniewski J, Zougman A, Nagaraj N, et al. Universal sample preparation method for proteome analysis[J]. Nature Methods, 2009, 6(5): 359-362.

[14] Sun W, Li F, Wu S, et al. Human urine proteome analysis by three separation approaches[J]. Proteomics, 2005, 5(18): 4994-5001.

[15] Hellstern S, Sasaki T, Fauser C, et al. Functional studies on recombinant domains of Mac-2-binding protein[J]. Journal of Biological Chemistry, 2002, 277(18): 15690-15696.

[16] Diaz-Sanchez A, Matilla A, Nuñez O, et al. Serum level of soluble vascular cell adhesion molecule in patients with hepatocellular carcinoma and its association with severity of liver disease[J]. Annals of hepatology, 2015, 12(2): 236-247.

[17] Ta D T, Guedens W, Vranken T, et al. Enhanced biosensor platforms for detecting the atherosclerotic biomarker VCAM1 based on bioconjugation with uniformly oriented VCAM1-targeting nanobodies[J]. Biosensors, 2016, 6(3): 34.

[18] Ferrín G, Ranchal I, Llamoza C, et al. Identification of candidate biomarkers for hepatocellular carcinoma in plasma of HCV-infected cirrhotic patients by 2-D DIGE[J]. Liver International, 2014, 34(3): 438-446.

[19] Chen R, Tan Y, Wang M, et al. Development of glycoprotein capture based label-free method for 
the high-throughput screening of differential glycoproteins in hepatocellular carcinoma[J]. Molecular \& Cellular Proteomics, 2011: mcp. M110. 006445.

[20] Kim H, Kim K, Yu S J, et al. Development of biomarkers for screening hepatocellular carcinoma using global data mining and multiple reaction monitoring[J]. PLoS One, 2013, 8(5): e63468.

[21] Ali O, Abo-Shadi M A, Hammad L N. The biological significance of serum complements C3 and $\mathrm{C} 4$ in HCV-related chronic liver diseases and hepatocellular carcinoma[J]. The Egyptian journal of immunology, 2005, 12(2): 91-99.

[22] Denning G M. IL-4 and IFN-gamma synergistically increase total polymeric IgA receptor levels in human intestinal epithelial cells. Role of protein tyrosine kinases[J]. The Journal of Immunology, 1996, 156(12): 4807-4814.

[23] Qi X, Li X, Sun X. Reduced expression of polymeric immunoglobulin receptor (pIgR) in nasopharyngeal carcinoma and its correlation with prognosis[J]. Tumor Biology, 2016, 37(8): 1109911104.

[24] Hindupur S K, Colombi M, Fuhs S R, et al. The protein histidine phosphatase LHPP is a tumour suppressor[J]. Nature, 2018, 555(7698): 678.

[25] Zheng J, Dai X, Chen H, et al. Down-regulation of LHPP in cervical cancer influences cell proliferation, metastasis and apoptosis by modulating AKT[J]. Biochemical and biophysical research communications, 2018, 503(2): 1108-1114.

[26] Huang C, Ding G, Gu C, et al. Decreased selenium-binding protein 1 enhances glutathione peroxidase 1 activity and downregulates HIF-1 $\alpha$ to promote hepatocellular carcinoma invasiveness[J]. Clinical Cancer Research, 2012.

[27] Ansong E, Ying Q, Ekoue D N, et al. Evidence that selenium binding protein 1 is a tumor suppressor in prostate cancer[J]. PLoS One, 2015, 10(5): e0127295.

[28] Chen X-L, Zhou L, Yang J, et al. Hepatocellular carcinoma-associated protein markers investigated by MALDI-TOF MS[J]. Molecular medicine reports, 2010, 3(4): 589-596.

[29] Naka T, He P, Serada S, et al. Proteomics-based identification of alpha-enolase as a tumor antigen in non-small lung cancer. AACR, 2006.

[30] Turner A M, Mcgowan L, Millen A, et al. Circulating DBP level and prognosis in operated lung cancer: an exploration of pathophysiology[J]. European Respiratory Journal, 2013, 41(2): 410-416.

[31] Anic G M, Weinstein S J, Mondul A M, et al. Serum vitamin D, vitamin D binding protein, and risk of colorectal cancer[J]. PloS one, 2014, 9(7): e102966.

[32] Chen S S, Yu K K, Ling Q X, et al. The combination of three molecular markers can be a valuable predictive tool for the prognosis of hepatocellular carcinoma patients[J]. Sci Rep, 2016, 6: 24582.

[33] Ahn Y H, Shin P M, Oh N R, et al. A lectin-coupled, targeted proteomic mass spectrometry (MRM MS) platform for identification of multiple liver cancer biomarkers in human plasma[J]. Journal of proteomics, 2012, 75(17): 5507-5515.

[34] Pan L, Aguilar H A, Wang L, et al. Three-dimensionally functionalized reverse phase glycoprotein array for cancer biomarker discovery and validation[J]. Journal of the American Chemical Society, 2016, 138(47): 15311-15314.

[35] Ahn Y H, Ji E S, Oh N R, et al. Differential proteomic approach for identification and verification of aberrantly glycosylated proteins in adenocarcinoma lung cancer (ADLC) plasmas by lectin-capturing and targeted mass spectrometry[J]. Journal of proteomics, 2014, 106: 221-229.

[36] Carmeci C, Thompson D A, Kuang W W, et al. Moesin expression is associated with the estrogen receptor-negative breast cancer phenotype[J]. Surgery, 1998, 124(2): 211-217. 
[37] Tao Q-F, Yuan S-X, Yang F, et al. Aldolase B inhibits metastasis through Ten-Eleven Translocation 1 and serves as a prognostic biomarker in hepatocellular carcinoma[J]. Molecular cancer, 2015, 14(1): 170 .

[38] Sun Y-L, Cai J-Q, Liu F, et al. Aberrant expression of peroxiredoxin 1 and its clinical implications in liver cancer[J]. World Journal of Gastroenterology: WJG, 2015, 21(38): 10840.

[39] Li S, Hu X, Ye M, et al. The prognostic values of the peroxiredoxins family in ovarian cancer[J]. Bioscience reports, 2018, 38(5): BSR20180667.

[40] Zhu X-W, Gong J-P. Expression and role of icam-1 in the occurrence and development of hepatocellular carcinoma[J]. Asian Pacific Journal of Cancer Prevention, 2013, 14(3): 1579-1583.

[41] Zhou F, Chen J, Tao G, et al. Increased levels of exhaled sICAM1, sVCAM1, and sE-selectin in patients with non-small cell lung cancer[J]. Respiratory medicine, 2014, 108(11): 1670-1676.

[42] Jenkinson C, Elliott V, Menon U, et al. Evaluation in pre-diagnosis samples discounts ICAM-1 and TIMP-1 as biomarkers for earlier diagnosis of pancreatic cancer[J]. Journal of proteomics, 2015, 113: 400-402.

[43] Chen R, Zhou X, Yu Z, et al. Low expression of LDHB correlates with unfavorable survival in hepatocellular carcinoma: strobe-compliant article[J]. Medicine, 2015, 94(39).

[44] Li C, Chen Y, Bai P, et al. LDHB may be a significant predictor of poor prognosis in osteosarcoma[J]. American journal of translational research, 2016, 8(11): 4831.

[45] Malik S, Bhatnagar S, Chaudhary N, et al. Elevated expression of complement C3 protein in chemically induced hepatotumorogenesis in Wistar rats: A correlative proteomics and histopathological study[J]. Experimental and toxicologic pathology, 2013, 65(6): 767-773.

[46] Lin K, He S, He L, et al. Complement component 3 is a prognostic factor of non-small cell lung cancer[J]. Molecular medicine reports, 2014, 10(2): 811-817.

[47] Jiang H, Ma N, Shang Y, et al. Triosephosphate isomerase 1 suppresses growth, migration and invasion of hepatocellular carcinoma cells[J]. Biochemical and biophysical research communications, 2017, 482(4): 1048-1053

[48] Cha Y J, Jung W H, Koo J S. Differential site-based expression of pentose phosphate pathwayrelated proteins among breast cancer metastases[J]. Disease markers, 2017, 2017.

[49] Feng X, Xie X, Zheng B, et al. The more potential performance of nidogen 2 methylation by tissue or plasma DNA over brichoalveolar lavage DNA in diagnosis of nonsmall cell lung cancer[J], 2018.

[50] Torky H A, Sherif A, Abolouz A, et al. Evaluation of Serum Nidogen-2 as a Screening and Diagnostic Tool for Ovarian Cancer[J]. Gynecol Obstet Invest, 2017.

[51] Lin Y, Lin G, Fang W, et al. Increased expression of annexin A1 predicts poor prognosis in human hepatocellular carcinoma and enhances cell malignant phenotype[J]. Medical Oncology, 2014, 31(12): 327.

[52] Hongsrichan N, Rucksaken R, Chamgramol Y, et al. Annexin A1: A new immunohistological marker of cholangiocarcinoma[J]. World journal of gastroenterology: WJG, 2013, 19(16): 2456.

[53] Fernandez R, Vizoso F, Rodriguez J, et al. Expression and prognostic significance of pepsinogen C in gastric carcinoma[J]. Annals of surgical oncology, 2000, 7(7): 508-514.

[54] Ueno N, Yoshida K, Hirose S, et al. Angiotensinogen-producing hepatocellular carcinoma[J]. Hypertension, 1984, 6(6 Pt 1): 931.

[55] Rosendahl M, Mosgaard B J, Høgdall C. The influence of cyst emptying, lymph node resection and chemotherapy on survival in stage ia and ic1 epithelial ovarian cancer[J]. Anticancer research, 2016, 36(10): 5373-5379. 
[56] Morita Y, Hayashi Y, Wang Y, et al. Expression of urokinase-type plasminogen activator receptor in hepatocellular carcinoma[J]. Hepatology, 1997, 25(4): 856-861.

[57] Itoh T, Hayashi Y, Kanamaru T, et al. Clinical significance of urokinase-type plasminogen activator activity in hepatocellular carcinoma[J]. Journal of gastroenterology and hepatology, 2000, 15(4): 422430.

[58] He H, Lü R, Xu J, et al. Preliminary study on the expression of cystatin C in primary liver cancer[J]. Sichuan da xue xue bao. Yi xue ban= Journal of Sichuan University. Medical science edition, 2013, 44(6): 920-923.

[59] Monsouvanh A, Proungvitaya T, Limpaiboon T, et al. Serum cathepsin B to cystatin C ratio as a potential marker for the diagnosis of cholangiocarcinoma[J]. Asian Pac J Cancer Prev, 2014, 15(21): 9511-9515.

[60] Borscheri N, Roessner A, Röcken C. Canalicular immunostaining of neprilysin (CD10) as a diagnostic marker for hepatocellular carcinomas[J]. The American journal of surgical pathology, 2001, 25(10): 1297-1303.

[61] Jana S H, Jha B M, Patel C, et al. CD10-A new prognostic stromal marker in breast carcinoma, its utility, limitations and role in breast cancer pathogenesis[J]. Indian Journal of Pathology and Microbiology, 2014, 57(4): 530.

[62] Pan D, Wang S, Ye H, et al. Ezrin expression in the primary hepatocellular carcinoma patients and associated with clinical, pathological characteristics[J]. Journal of cancer research and therapeutics, 2016, 12(8): 291.

[63] Clapéron A, Debray D, Redon M-J, et al. Immunohistochemical profile of ezrin and radixin in human liver epithelia during fetal development and pediatric cholestatic diseases[J]. Clinics and research in hepatology and gastroenterology, 2013, 37(2): 142-151.

[64] Arumugam P, Partelli S, Coleman S J, et al. Ezrin expression is an independent prognostic factor in gastro-intestinal cancers[J]. Journal of Gastrointestinal Surgery, 2013, 17(12): 2082-2091.

[65] Ghaffari A, Hoskin V, Szeto A, et al. A novel role for ezrin in breast cancer angio/lymphangiogenesis[J]. Breast Cancer Research, 2014, 16(5): 438.

[66] Huang L, Li J, Yan J-J, et al. Prealbumin is predictive for postoperative liver insufficiency in patients undergoing liver resection[J]. World Journal of Gastroenterology: WJG, 2012, 18(47): 7021.

[67] Zhang Y, Fan Y, Mei Z. NGAL and NGALR overexpression in human hepatocellular carcinoma toward a molecular prognostic classification[J]. Cancer epidemiology, 2012, 36(5): e294-e299.

[68] Bulska M, Kudłacz K, Szcześniak P. Role of oncogene 24p3 neutrophil gelatinase-associated lipocalin (NGAL) in digestive system cancers[J]. Postepy higieny i medycyny doswiadczalnej (Online), 2016, 70: 1026-1031.

[69] Roli L, Pecoraro V, Trenti T. Can NGAL be employed as prognostic and diagnostic biomarker in human cancers? A systematic review of current evidence[J]. The International journal of biological markers, 2017, 32(1): 53-61.

[70] Tamai T, Uto H, Takami Y, et al. Serum manganese superoxide dismutase and thioredoxin are potential prognostic markers for hepatitis $\mathrm{C}$ virus-related hepatocellular carcinoma[J]. World journal of gastroenterology: WJG, 2011, 17(44): 4890.

[71] Mollbrink A, Jawad R, Vlamis-Gardikas A, et al. Expression of thioredoxins and glutaredoxins in human hepatocellular carcinoma: correlation to cell proliferation, tumor size and metabolic syndrome[J]. International journal of immunopathology and pharmacology, 2014, 27(2): 169-183.

[72] Zhu J, Lin Z, Wu J, et al. Analysis of serum haptoglobin fucosylation in hepatocellular carcinoma 
and liver cirrhosis of different etiologies[J]. Journal of proteome research, 2014, 13(6): 2986-2997.

[73] Asazawa H, Kamada Y, Takeda Y, et al. Serum fucosylated haptoglobin in chronic liver diseases as a potential biomarker of hepatocellular carcinoma development[J]. Clinical Chemistry and Laboratory Medicine (CCLM), 2015, 53(1): 95-102.

[74] Shu H, Kang X, Guo K, et al. Diagnostic value of serum haptoglobin protein as hepatocellular carcinoma candidate marker complementary to $\alpha$ fetoprotein[J]. Oncology reports, 2010, 24(5): 12711276.

[75] Sun L, Pan J, Peng L, et al. Combination of haptoglobin and osteopontin could predict colorectal cancer hepatic metastasis[J]. Annals of surgical oncology, 2012, 19(7): 2411-2419.

[76] Li H, Li C, Wu H, et al. Identification of Apo-A1 as a biomarker for early diagnosis of bladder transitional cell carcinoma[J]. Proteome science, 2011, 9(1): 21.

[77] Walaszczyk A, Pietrowska M, Wojakowska A, et al. Therapy-Related Changes in the Serum Proteome Patterns of Early Stage Breast Cancer Patients with Different Outcomes[J]. Protein and peptide letters, 2017, 24(1): 37-45.

[78] Chang Y-K, Lai Y-H, Chu Y, et al. Haptoglobin is a serological biomarker for adenocarcinoma lung cancer by using the ProteomeLab PF2D combined with mass spectrometry[J]. American journal of cancer research, 2016, 6(8): 1828.

[79] Perumal J, Balasundaram G, Mahyuddin A P, et al. SERS-based quantitative detection of ovarian cancer prognostic factor haptoglobin[J]. International journal of nanomedicine, 2015, 10: 1831.

[80] Humphries J M, Penno M A, Weiland F, et al. Identification and validation of novel candidate protein biomarkers for the detection of human gastric cancer[J]. Biochimica et Biophysica Acta (BBA)-Proteins and Proteomics, 2014, 1844(5): 1051-1058.

[81] Yokoyama Y, Kuramitsu Y, Takashima M, et al. Protein level of apolipoprotein E increased in human hepatocellular carcinoma[J]. International journal of oncology, 2006, 28(3): 625-631.

[82] Masuda N, Ogawa O, Park M, et al. Meta-analysis of a 10-plex urine-based biomarker assay for the detection of bladder cancer[J]. Oncotarget, 2018, 9(6): 7101.

[83] Wang X, Bai L, Ibrahim M M, et al. Evaluation of Annexin A7, Galectin-3 and Gelsolin as possible biomarkers of hepatocarcinoma lymphatic metastasis[J]. Biomedicine \& Pharmacotherapy, 2014, 68(3): 259-265.

[84] Lokamani I, Looi M-L, Ali S a M, et al. Gelsolin and ceruloplasmin as potential predictive biomarkers for cervical cancer by 2D-DIGE proteomics analysis[J]. Pathology \& Oncology Research, 2014, 20(1): 119-129.

[85] Tsai M-H, Wu C-C, Peng P-H, et al. Identification of secretory gelsolin as a plasma biomarker associated with distant organ metastasis of colorectal cancer[J]. Journal of molecular medicine, 2012, 90(2): $187-200$

[86] Fan N-J, Gao C-F, Wang C-S, et al. Discovery and verification of gelsolin as a potential biomarker of colorectal adenocarcinoma in a Chinese population: Examining differential protein expression using an iTRAQ labelling-based proteomics approach[J]. Canadian Journal of Gastroenterology and Hepatology, 2012, 26(1): 41-47.

[87] Danilov A V, Danilova O V, Brown J R, et al. Dipeptidyl peptidase 2 apoptosis assay determines the B-cell activation stage and predicts prognosis in chronic lymphocytic leukemia[J]. Experimental hematology, 2010, 38(12): 1167-1177.

[88] Jelski W, Kedra B, Szmitkowski M. Alcohol dehydrogenase and aldehyde dehydrogenase as tumour markers and factors intensifying carcinogenesis in liver cancer[J]. Polski merkuriusz lekarski: organ 
Polskiego Towarzystwa Lekarskiego, 2008, 25(146): 141-144.

[89] Orywal K, Jelski W, Zdrodowski M, et al. The diagnostic value of alcohol dehydrogenase isoenzymes and aldehyde dehydrogenase measurement in the sera of patients with endometrial cancer[J]. Anticancer research, 2013, 33(9): 3725-3730.

[90] Jelski W, Kutylowska E, Laniewska-Dunaj M, et al. Alcohol dehydrogenase (ADH) and aldehyde dehydrogenase $(\mathrm{ALDH})$ as candidates for tumor markers in patients with pancreatic cancer[J]. J Gastrointestin Liver Dis, 2011, 20(3): 255-259.

[91] Zhao J, Chi A, Mao R, et al. Serum Amyloid P-component Level May be a Biomarker for Lung Toxicities and Overall Survival after Thoracic Radiotherapy for Non-small Cell Lung Cancer[J]. Clinical laboratory, 2016, 62(11): 2183-2190.

[92] Wang Z, Wang C, Huang X, et al. Differential proteome profiling of pleural effusions from lung cancer and benign inflammatory disease patients[J]. Biochimica et Biophysica Acta (BBA)-Proteins and Proteomics, 2012, 1824(4): 692-700.

[93] Watanabe H, Imaizumi M, Ojika T, et al. Evaluation of biological characteristics of lung cancer by the human $28 \mathrm{kDa}$ vitamin D-dependent calcium binding protein, calbindin-D28k[J]. Japanese journal of clinical oncology, 1994, 24(3): 121-127.

[94] Li N, Zhu Q, Yang C, et al. Elevated serum soluble CD14 levels in chronic HBV infection are significantly associated with HBV-related hepatocellular carcinoma[J]. Tumor Biology, 2016, 37(5): 6607-6617.

[95] Khwaja F W, Dukecohan J S, Brat D J, et al. Attractin Is Elevated in the Cerebrospinal Fluid of Patients with Malignant Astrocytoma and Mediates Glioma Cell Migration[J]. Clinical Cancer Research An Official Journal of the American Association for Cancer Research, 2006, 12(21): 6331.

[96] Montaser M F, Sakr M A, Khalifa M O. Alpha-L-fucosidase as a tumour marker of hepatocellular carcinoma[J]. Arab Journal of Gastroenterology, 2012, 13(1): 9-13.

[97] Yeh C B, Yu Y L, Lin C W, et al. Terminalia catappa attenuates urokinase-type plasminogen activator expression through Erk pathways in Hepatocellular carcinoma[J]. Bmc Complementary \& Alternative Medicine, 2014, 14(1): 141.

[98] Kos J, ., Stabuc B, ., Schweiger A, ., et al. Cathepsins B, H, and L and their inhibitors stefin A and cystatin C in sera of melanoma patients[J]. Clinical Cancer Research An Official Journal of the American Association for Cancer Research, 1997, 3(10): 1815-22.

[99] Re E C, Del, Shuja S, ., Cai J, ., et al. Alterations in cathepsin H activity and protein patterns in human colorectal carcinomas[J]. British Journal of Cancer, 2000, 82(7): 1317-1326.

[100] Anuradha W, Daniel K, Sloane B F, et al. Analysis of a truncated form of cathepsin H in human prostate tumor cells[J]. Journal of Biological Chemistry, 2002, 277(13): 11533-8.

[101] Cb V D B, Duvekot J J, Güzel C, et al. Elevated levels of protein AMBP in cerebrospinal fluid of women with preeclampsia compared to normotensive pregnant women[J]. Proteomics Clin Appl, 2016, 11(1-2).

[102] Shweta T, Milan S, Anindita Kar R, et al. The ORF3 protein of hepatitis E virus interacts with liver-specific alpha1-microglobulin and its precursor alpha1-microglobulin/bikunin precursor (AMBP) and expedites their export from the hepatocyte[J]. Journal of Biological Chemistry, 2004, 279(28): 29308-29319.

[103] Bram D C, Geert B. Regulatory networks defining EMT during cancer initiation and progression[J]. Nature Reviews Cancer, 2013, 13(2): 97-110.

[104] Thiery J P, Acloque H, Huang R Y, et al. Epithelial-mesenchymal transitions in development and 
disease[J]. Cell, 2009, 139(5): 871-890.

[105] Tatsuro I, Kundu R K, Eugene Y, et al. Targeted disruption of endothelial cell-selective adhesion molecule inhibits angiogenic processes in vitro and in vivo[J]. Journal of Biological Chemistry, 2003, 278(36): 34598-34604.

[106] Qu J, Sun W, Zhong J, et al. Correction: Phosphoglycerate mutase 1 regulates dNTP pool and promotes homologous recombination repair in cancer cells[J]. Journal of Cell Biology, 2017, 216(2): jcb.201607008.

[107] Schreiber R D, Old L J, Smyth M J. Cancer immunoediting: integrating immunity's roles in cancer suppression and promotion[J]. Science, 2011, 331(6024): 1565-1570.

[108] Gambhir S S. Molecular imaging of cancer with positron emission tomography[J]. Nature Reviews Cancer, 2002, 2(9): 683.

[109] Beluzi M, Peres S B, Henriques F S, et al. Pioglitazone treatment increases survival and prevents body weight loss in tumor-bearing animals: possible anti-cachectic effect[J]. PloS one, 2015, 10(3): e0122660.

[110] De Fatima Silva F, Ortiz-Silva M, De Souza Galia W B, et al. Pioglitazone improves insulin sensitivity and reduces weight loss in Walker-256 tumor-bearing rats[J]. Life sciences, 2017, 171: 68-74. [111] Zhang L, Li Y, Meng W, et al. Dynamic urinary proteomic analysis in a Walker 256 intracerebral tumor model[J]. bioRxiv, 2018: 481697.

[112] Wei J, Ni N, Zhang L, et al. Early candidate biomarkers in urine of Walker-256 lung metastasis rat model[J]. bioRxiv, 2018: 306050 .

[113] Atsushi M, Minoru T, Tohru I. Stem/progenitor cells in liver development, homeostasis, regeneration, and reprogramming[J]. Cell Stem Cell, 2014, 14(5): 561-574.

[114] Iacovazzi P A, Trisolini A, Barletta D, et al. Serum 90K/MAC-2BP glycoprotein in patients with liver cirrhosis and hepatocellular carcinoma: a comparison with $\alpha$-fetoprotein[J]. Clinical chemistry and laboratory medicine, 2001, 39(10): 961-965.

[115] Grassadonia A, Tinari N, Iurisci I, et al. 90K (Mac-2 BP) and galectins in tumor progression and metastasis[J]. Glycoconjugate journal, 2002, 19(7-9): 551-556.

[116] Ouda S, Khairy A, Sorour A E, et al. Serum Beta-2 microglobulin: a possible marker for disease progression in egyptian patients with chronic HCV related liver diseases[J]. Asian Pacific Journal of Cancer Prevention, 2015, 16(17): 7825-7829.

[117] Yue X, Ai J, Xu Y, et al. Polymeric immunoglobulin receptor promotes tumor growth in hepatocellular carcinoma[J]. Hepatology, 2017, 65(6): 1948-1962. 